\title{
Presidencialismos em Perspectiva Comparada: Argentina, Brasil e Uruguai*
}

\author{
Luzia Helena Herrmann de Oliveira
}

$\mathrm{E}$ studos recentes têm procurado mostrar a influência dos desenhos institucionais sobre a atividade política nos sistemas presidencialistas multipartidários. Uma questão de interesse são os modelos sob os quais essas democracias operam, seja para concentrar poder nas mãos do Executivo seja, contrariamente, para facilitar a participação dos partidos e da sociedade nos mecanismos decisórios.

Ao analisar as relações entre Executivo e Legislativo nos sistemas presidencialistas latino-americanos, Mainwaring e Shugart (1999) afirmam que o presidente da República pode controlar o Legislativo, desde que ao menos um dos seguintes fatores esteja presente: que o presidente mantenha o controle partidário, ou seja, que a base aliada do Legislativo se constitua em maioria, garantindo apoio às propostas governamentais; que o presidente detenha poderes legislativos constitucionalmente determinados, os quais lhe possibilitam interferir decisi-

\footnotetext{
*O artigo foi desenvolvido durante o estágio de pós-doutorado no Instituto Ibero América e Portugal (USAL, Espanha), com apoio da Coordenação de Aperfeiçoamento de Pessoal de Nível Superior - Capes, e apresentado no XXIX Encontro Anual da Associação Nacional de Pós-Graduação e Pesquisa em Ciências Sociais - Anpocs, realizado em 2005. Sou grata a todo o pessoal do Instituto, pela acolhida atenciosa, e especialmente a Mercedes García, Francisco Sánchez López e Manuel Alcántara, que leram e discutiram o trabalho desde sua primeira versão. Agradeço também a Paulo Herrmann de Oliveira, que me auxiliou na confecção das tabelas, e a Maria José de Rezende e colegas do Grupo de Trabalho "Estudos Legislativos", sobretudo André Marenco, pelas sugestões que procurei incorporar nesta versão final.
}

DADOS - Revista de Ciências Sociais, Rio de Janeiro, Vol. 49, n-2, 2006, pp. 301 a 343. 
vamente na atividade legislativa. Estes poderes constitucionais atuam no sentido de fortalecer o presidente da República, mesmo nos casos em que inexista um sólido apoio político-partidário.

Segundo os autores, os desenhos político-institucionais na América Latina são bastante variados, mas os poderes legislativos do Executivo estão previstos na maior parte das constituições, atuando de duas formas: para garantir, de modo unilateral, a mudança do status quo legislativo; ou para impedir que a mudança legislativa seja feita, evitando que determinada legislação entre em vigor, na íntegra ou parcialmente. No primeiro caso, denominado "poderes proativos" do presidente da República, encontram-se várias prerrogativas constitucionais, como o direito exclusivo de legislar sobre determinadas matérias, o direito à iniciativa exclusiva $\mathrm{e}$ - mais importante - o direito de editar decretos de necessidade e urgência com força de lei. Ao direito de barrar a legislação, Mainwaring e Shugart (1999) denominam "poderes reativos" do presidente, destacando-se aí o direito parcial ou integral de veto.

Embora se reconheça a importância desse tipo de intervenção do Executivo para determinar o caráter da relação entre poderes, análises recentes vêm demonstrando que, constitucionalmente, também o Legislativo possui prerrogativas essenciais, sendo, também ele, dotado de poderes - proativos e reativos. Os desenhos político-institucionais das democracias modernas possuem capacidades diferenciadas para operacionalizar mudanças nas políticas públicas. Conforme mostra Tsebelis (1997), a estabilidade das políticas encontra-se diretamente relacionada às características dos diversos veto players contidos no sistema. Essa concepção de veto player nasceu com o constitucionalismo moderno, a partir da noção de que o equilíbrio político depende de uma bem-arquitetada construção de pesos e contrapesos institucionais, previstos na Constituição (os chamados veto players institucionais) ${ }^{1}$.

Considera-se veto player os atores, individuais e coletivos, que participam das decisões políticas, sendo requerida a sua concordância para que determinada política seja alterada. O número de vetos institucionais encontra-se definido pela Constituição, podendo ser medido pelo cálculo de atores com capacidade formal de bloquear a mudança do status quo político. Tsebelis destaca que o bicameralismo, o veto presidencial, a exigência das maiorias qualificadas, a regulamentação dos referendos e tantas outras regulamentações contidas nos sistemas polí- 
ticos, interferem no sentido de determinar quais são os atores com capacidade de veto.

Nas democracias, o Legislativo aparece como um canal crucial de mediação entre o processo decisório governamental e as demandas pluralistas que partem da sociedade. Alguns desenhos institucionais, sejam parlamentaristas ou presidencialistas, procuram fortalecer as funções legislativas e fiscalizadoras do Legislativo. Como salienta Jorge Lanzaro (2003) em estudo comparado, os sistemas presidencialistas da América Latina organizam-se segundo uma variedade de modalidades que devem ser distinguidas. Tal como nos sistemas parlamentaristas, os presidencialismos diferenciam-se por apresentar desenhos ora de caráter pluralista, ora de tendência nitidamente majoritária.

Segundo o modelo de Lijphart $(1984 ; 2003)$ sobre democracias majoritárias e consensuais, o poder concentra-se à medida que se fecha entre poucos atores, e se distribui quando o nível da negociação política se amplia, envolvendo um número maior de grupos e partidos. As decisões tendem a ser mais concentradoras à medida que se encontram mais fechadas em torno do Poder Executivo. Normas que objetivam a eficácia tendem a concentrar poder. De modo inverso, à medida que $\mathrm{o}$ tempo exigido para aprovação se estende com a participação de um número maior de parlamentares e segmentos da sociedade no processo, o poder tende a se equilibrar e se distribuir.

Neste artigo essas questões são analisadas comparando-se o arcabouço constitucional de três democracias da América do Sul - Argentina, Brasil e Uruguai. Os três países apresentam pontos comuns em seus desenhos institucionais, mas, conforme se pretende demonstrar a seguir, há diferenças constitutivas que devem ser consideradas. Os desenhos apresentam variações significativas no modo como são estruturados.

O artigo procura, em primeiro lugar, definir os indicadores institucionais que determinam o grau de concentração e dispersão do poder nas democracias presidencialistas e, em segundo lugar, construir um índice de concentração, caracterizando as três democracias. Os aspectos abordados vêm sendo considerados pela literatura política como de grande relevância no relacionamento entre poderes. O exercício comparativo foi possível, pois já existe um número substancial de pesquisas sobre América Latina que serviu de referência ${ }^{2}$. 
O texto divide-se em três partes. Na primeira, são examinadas as normas que possibilitam a participação direta da sociedade no processo legislativo. Na segunda, procura-se apresentar a legislação sobre os poderes do Legislativo, bem como o problema do veto dos atores no processo de tomada de decisões. No terceiro, entra-se no ponto central dos poderes proativos e reativos do presidente da República.

A comparação entre os três países é formulada em 12 tabelas do tipo escala de Likert, com espaço entre 0 e 1 , sendo 0 considerada a situação de máxima concentração de poder e 1 de máxima desconcentração. No final é construído um índice comparativo.

\section{MECANISMOS INSTITUCIONAIS DE PARTICIPAÇÃO DIRETA}

A Constituição brasileira afirma expressamente que "o poder emana do povo" (art. 1) que o exerce por meio de representantes ou diretamente. A Constituição uruguaia determina que a soberania será exercida diretamente, pelo corpo eleitoral, pela iniciativa e pelo referendo, e, indiretamente, pelo corpo de representantes (art. 82). A Argentina opta pelo sistema representativo (art. 22), mas adota mecanismos de atuação direta, como o referendo e a iniciativa legislativa (art. 39 e art. 40). Portanto, nos três países existe uma definição constitucional sobre os mecanismos de participação popular efetiva.

Entre essas formas destacam-se três: a participação da sociedade no processo legislativo, por meio das audiências públicas; a iniciativa legislativa popular e, finalmente, a decisão legislativa direta, por meio de referendos e plebiscitos. A Tabela 1 descreve como essas questões são tratadas pelas constituições dos três países, ressaltando que a regulamentação nem sempre corresponde ao uso que a sociedade faz dela ${ }^{3}$.

Além disso, é necessário considerar que as diferentes modalidades de regulamentação resultam em formas de participação potencialmente diversas. Isso foi levado em consideração na Tabela 1, que estabeleceu pesos diferenciados de acordo com a forma de participação. A seguir são explicadas as razões que justificam a utilização desses valores, procurando, assim, atenuar o grau de subjetividade da pontuação.

As audiências públicas têm possibilitado que segmentos da sociedade participem das discussões legislativas, apresentando pontos de vista que ora correspondem a visões técnicas a respeito do assunto em questão, ora têm a função de trazer sem subterfúgios os interesses específi- 
Presidencialismos em Perspectiva Comparada: Argentina, Brasil e Uruguai

Tabela 1

Regras de Participação Direta nas Decisões Legislativas

\begin{tabular}{|c|c|c|c|c|c|c|c|}
\hline Indicadores & Peso & \multicolumn{2}{|r|}{ Tipos } & Ponto & Argentina & Brasil & Uruguai \\
\hline \multirow{3}{*}{$\begin{array}{l}\text { Audiência } \\
\text { Pública }\end{array}$} & \multirow[t]{3}{*}{1} & \multirow{3}{*}{\multicolumn{2}{|c|}{$\begin{array}{l}\text { Não há } \\
\text { Rotineiras } \\
\text { Comissões }\end{array}$}} & 0 & & & 0 \\
\hline & & & & 0,5 & & & \\
\hline & & & & 1,0 & 1,0 & 1,0 & \\
\hline \multirow{12}{*}{$\begin{array}{l}\text { Iniciativa } \\
\text { Legislativa Po- } \\
\text { pular }\end{array}$} & \multirow[t]{3}{*}{1} & \multirow{3}{*}{\multicolumn{2}{|c|}{$\begin{array}{l}\text { Não há } \\
\text { Há, mas não está regulamentada } \\
\text { Há }\end{array}$}} & 0 & & & \\
\hline & & & & 0,5 & & & 0,5 \\
\hline & & & & 1,0 & 1,0 & 1,0 & \\
\hline & \multirow[t]{2}{*}{1} & \multirow{2}{*}{$\begin{array}{l}\text { Restrições ao } \\
\text { uso }\end{array}$} & + de 4 & 0 & 0 & 0 & 0 \\
\hline & & & Até 4 & 1,0 & & & \\
\hline & \multirow[t]{5}{*}{1} & \multirow{5}{*}{$\begin{array}{l}\text { Percentual de } \\
\text { eleitores exi- } \\
\text { gidos }\end{array}$} & Até $1 \%$ & 1,0 & & 1,0 & \\
\hline & & & $1 \%$ a $2 \%$ & 0,75 & 0,75 & & \\
\hline & & & $2 \%$ a $5 \%$ & 0,5 & & & \\
\hline & & & $+5 \%$ & 0,25 & & & 0,25 \\
\hline & & & Não há & 0 & & & \\
\hline & \multirow[t]{2}{*}{1} & \multirow{2}{*}{$\begin{array}{l}\text { Prazo de vo- } \\
\text { tação }\end{array}$} & Sim & 1,0 & 1,0 & & \\
\hline & & & Não & 0 & & 0 & 0 \\
\hline \multirow{14}{*}{$\begin{array}{l}\text { Plebiscito e } \\
\text { Referendo }\end{array}$} & \multirow[t]{2}{*}{2} & \multirow[t]{2}{*}{ Iniciativa } & Legislativo & 1,0 & 1,0 & 1,0 & 1,0 \\
\hline & & & Executivo & 0 & & & \\
\hline & \multirow[t]{2}{*}{2} & Iniciativa da & Sim & 1,0 & 0 & 0 & 1,0 \\
\hline & & sociedade $^{4}$ & Não & 0 & & & 0 \\
\hline & \multirow[t]{4}{*}{2} & \multirow{4}{*}{$\begin{array}{l}\text { Exigência } \\
\text { para } \\
\text { proposta de } \\
\text { lei }\end{array}$} & Não há & 0 & & & \\
\hline & & & Maioria absoluta & 0,5 & 0,5 & & \\
\hline & & & $\begin{array}{l}2 / 5 \text { do Legislati- } \\
\text { vo }\end{array}$ & 0,75 & & & \\
\hline & & & $\begin{array}{l}1 / 3 \text { do Legislati- } \\
\text { vo }\end{array}$ & 1,0 & & 1,0 & \\
\hline & \multirow[t]{4}{*}{2} & \multirow{4}{*}{$\begin{array}{l}\text { Exigência } \\
\text { para } \\
\text { proposta de } \\
\text { emenda } \\
\text { constitucio- } \\
\text { nal }\end{array}$} & Não há & 0 & 0 & & \\
\hline & & & Maioria absoluta & 0,5 & & & \\
\hline & & & $\begin{array}{l}2 / 5 \text { do Legislati- } \\
\text { vo }\end{array}$ & 0,75 & & & 0,75 \\
\hline & & & $\begin{array}{l}\text { 1/3 do Legislati- } \\
\text { vo }\end{array}$ & 1,0 & & 1,0 & \\
\hline & \multirow[t]{2}{*}{2} & \multirow{2}{*}{$\begin{array}{l}\text { Derrubada } \\
\text { de lei }\end{array}$} & Sim & 1,0 & & & 1,0 \\
\hline & & & Não & 0 & 0 & 0 & \\
\hline \multicolumn{5}{|c|}{ Média Ponderada } & 0,45 & 0,60 & 0,55 \\
\hline
\end{tabular}

Fontes: Elaborada com base em García Montero (2004); Alcántara Sáez, García Montero e Sánches Lópes (2005a; 2005b); Constitución de la República Oriental del Uruguay; Constituição da República Federal do Brasil; Constitución de la Nación Argentina; Lei no 9.709/98, Brasil. 
cos para dentro do debate parlamentar. Em qualquer dos casos, trata-se de um avanço no sentido de estreitar a relação entre representantes e representados:

a) Algumas legislações latino-americanas que adotam a prática das audiências públicas estabelecem que em determinada data o legislativo é aberto à sociedade, para que esta apresente queixas e sugestões. Outras abrem a participação dentro das comissões. Estas receberam pontuação mais alta na tabela porque parecem mais eficazes. É de se supor que grupos especializados que defendem questões diretamente relacionadas à discussão em pauta tenham mais capacidade de interferir nos resultados dos trabalhos do que pessoas e grupos que se apresentem em sessões parlamentares rotineiras. Brasil e Argentina adotam a norma das audiências públicas nas comissões ${ }^{5}$.

b) As audiências, contudo, não possuem caráter vinculante, ou seja, as posturas defendidas nas audiências não têm relação com as conclusões a que devam chegar os parlamentares ${ }^{6}$. Nesse sentido, embora se reconheça que elas são um estágio importante do debate público, considera-se que o peso das audiências é relativamente menor do que o das outras formas de participação.

Na iniciativa legislativa popular, a possibilidade de interferência da sociedade é maior porque, de fato, a iniciativa pode resultar em lei. Trata-se de uma forma de participação direta presente em nove democracias latino-americanas. A escala da pontuação é relativa ao grau de dificuldade em participar; quanto maior a dificuldade, menor a pontuação na escala:

a) É sempre exigido um número mínimo de assinaturas, mas esse mínimo varia desde um percentual inferior a $1 \%$ dos eleitores a $25 \%$, como no caso do Uruguai.

b) O segundo fator é a lista de temas proibitivos. Argentina (art. 39), Brasil (art. 61) e Uruguai (art. 79 e art. 82) impõem mais de quatro questões em que a iniciativa popular não pode legislar.

c) Finalmente, há o fato de que essas normas constitucionais são muito enxutas, necessitando de legislação complementar para regularizálas. Alguns países, como o Uruguai, permanecem sem a regulamentação ${ }^{7}$. 
A terceira modalidade de participação popular direta são os plebiscitos e referendos, que receberam peso mais alto na tabela. Trata-se de um tema controverso dentro da literatura política, cabendo dúvidas sobre o quanto tais mecanismos contribuiriam para a ampliação da participação popular ou, inversamente, tenderiam a fortalecer o Executivo em detrimento de uma maior distribuição do poder.

Esse debate é fundamentado em princípios divergentes: um, de inspiração rousseauniana, tende a enfatizar a importância da participação política na vida republicana; outro, eminentemente liberal, procura ressaltar a interferência indevida que essa prática pode provocar sobre o equilíbrio entre poderes. Segundo estes, a convocação direta da sociedade tem, no mais das vezes, o objetivo de manipular a opinião pública e fortalecer o Executivo, concentrando poder: "desde seu início, há cerca de dois séculos, plebiscitos e referendos foram quase sempre um jogo de cartas marcadas, com o objetivo de legitimar decisões autoritárias, ratificar ocupações de território alheio, e assim por diante" (Lamounier, 2005:280).

Sem dúvida, ambos os argumentos devem ser levados em consideração, sobretudo na análise das novas democracias da América Latina, que mantêm um nível baixo de participação política e trazem a herança de governos plebiscitários e populistas. Trata-se de uma discussão relevante sobre o caráter da democracia, mas que escapa aos objetivos deste artigo.

Entretanto, um aspecto que merece ser lembrado é o modo como essas regras são regulamentadas, uma vez que mesmo entre países da América Latina há diferenças que provavelmente interferem no teor pretensamente mais majoritário ou mais consensual dos sistemas políticos. Por exemplo, nas constituições da Venezuela e Chile, a iniciativa do referendo cabe ao Poder Executivo, o que indica uma tendência de controle por parte do presidente da República. Mas essa é uma norma incomum, porque na maioria dos casos latino-americanos é o Legislativo quem deve determinar a realização de consultas populares e, fundamentalmente, elas ocorrem quando o Legislativo não detém uma maioria sólida para decidir sobre questões polêmicas; trata-se, portanto, de um recurso em favor das minorias.

Os detalhes da regulamentação devem ser considerados. Segundo Lijphart (2003:260), o mecanismo do referendo é bastante utilizado para ratificar emendas constitucionais, mas, dependendo da forma 
como são regulamentados, podem favorecer a centralização do poder ou, contrariamente, as minorias políticas. Referendos que exigem maiorias simples de votos populares favorecem o Executivo. Mas esse é um caso raro, pois na grande maioria dos casos o "referendo é determinado em acréscimo à aprovação legislativa por maiorias ordinárias ou extraordinárias, tornando as emendas mais difíceis de serem aprovadas e as constituições mais rígidas".

Finalmente, cabe observar que é possível restringir a amplitude dos temas passíveis de consulta popular, corrigindo-se, assim, os riscos inerentes ao mecanismo. A Constituição brasileira, por exemplo, proíbe emendas constitucionais tendentes a abolir a forma federativa do Estado; o voto direto, secreto, universal e periódico; a separação dos poderes; e os direitos e garantias individuais (art. 60, §4ํ). Há muitas possibilidades de regulamentação, e a idéia contida na Tabela 1 é que o sistema se torna mais consensual à medida que transfere para a sociedade as decisões políticas.

No Uruguai, os referendos são utilizados com freqüência. Embora a política uruguaia não preveja a prática das audiências públicas, nem tenha regulamentado a iniciativa legislativa popular, na terceira modalidade, a dos referendos e plebiscitos, sua posição se inverte. Nesse país, a possibilidade de referendo apresenta uma inovação em relação ao caso mais comum, que é a solicitação pelo Legislativo (como acontece com a Argentina e $\mathrm{Brasil}^{8}$ ). No Uruguai, o pedido de referendo pode partir da própria população, com a apresentação de $10 \%$ de adesões de eleitores (art. 331). E tanto no Brasil quanto no Uruguai a minoria do Legislativo pode propor um plebiscito para emendar a Constituição, convocando a sociedade a decidir.

Uma segunda forma de referendo permitido pela Constituição uruguaia é o "referendo contra as leis" (art. 79). Trata-se de uma convocação partindo da própria sociedade, para que esta responda se concorda ou não com uma determinada legislação recentemente promulgada ${ }^{9}$. Cabe lembrar que a Lei no 16.017 / 89, que regulamentava o artigo constitucional, exigia um percentual mínimo de $0,5 \%$ para solicitar o plebiscito. Contudo, no ano 2000 a legislação foi reformulada, aumentando a exigência para $25 \%$ dos eleitores (em até um ano depois de a legislação ter sido aprovada).

Comparativamente à Argentina, Brasil e Uruguai apresentam um número maior de normas que favorecem a participação da sociedade. 
Obviamente, essa constatação não pretende indicar que essas sociedades sejam mais participativas, pois, para sabê-lo, seria necessário desenvolver outro tipo de pesquisa. Considerando-se que as regras exercem alguma influência, os dois países equiparam-se, embora a desconcentração brasileira seja ligeiramente mais ampla, visto que permite os três tipos de participação.

\section{ATORES COM POSSIBILIDADE DE VETO NO PROCESSO LEGISLATIVO}

O segundo aspecto abordado neste artigo - a regulamentação dos canais de representação - recai na clássica discussão sobre a participação política de uma multiplicidade de atores e risco de paralisia decisória. Como estabelecer o equilíbrio democrático entre representação e eficácia? A seguir, serão apresentados seis indicadores que mostram como os três países enfrentaram esse dilema ao organizar a estrutura institucional do Legislativo.

\section{Sistema Político-Eleitoral}

Um primeiro aspecto a ser analisado é a regulamentação do sistema político, conforme é mostrado na Tabela 2:

1. O modo como acontecem as eleições presidenciais pode influenciar na composição do Legislativo, interferindo no percentual de apoio ao presidente da República.

a) Quando as datas das eleições coincidem, cresce a possibilidade de que os partidos de apoio ao presidente recebam um número maior de votos e, conseqüentemente, um número maior de cadeiras (Mainwaring e Shugart, 1999; Colomer e Negretto, 2003). Portanto, datas coincidentes tendem a fortalecer o presidente da República. Brasil e Uruguai realizam eleições para escolha do presidente e do corpo legislativo na mesma data. Na Argentina há uma combinação parcial: para a Câmara de Deputados, as eleições acontecem a cada dois anos, com preenchimento de $50 \%$ das cadeiras em cada eleição, sendo, portanto, apenas $50 \%$ coincidentes com a eleição presidencial; para o Senado, as eleições são feitas em três etapas, de dois em dois anos, o que leva à coincidência de datas somente para $1 / 3$ dos senadores. Na tabela, a data da eleição foi considerada como um indicador de menor impacto; todos os outros receberam peso dois. 
b) Regras de maioria simples facilitam a vitória de um presidente apoiado por uma minoria. A exigência da maioria absoluta garante um apoio mais amplo ao presidente, desconcentrando poder. Brasil e Uruguai exigem maioria absoluta, prevendo a realização do segundo turno sempre que esse patamar não tenha sido alcançado. Na Argentina, vigora o sistema de maioria relativa, não ocorrendo segundo turno quando o candidato mais votado tiver obtido um mínimo de $45 \%$ dos votos.

2. A variável federalismo encontra-se relacionada ao grau de pluralismo da sociedade. Estados federativos são considerados mais consensuais porque provocam uma desconcentração do poder, que se distribui pelas esferas regionais, com o objetivo de oferecer maior autonomia a grupos sociais minoritários. São os países de grande extensão territorial e os países divididos pelo pluralismo regional, religioso, étnico e lingüístico, que costumam adotar o sistema federativo. O Uruguai é um Estado unitário; Brasil e Argentina - dois países em que a clivagem regional exerce certo peso - são federativos ${ }^{10}$.

3. O bicameralismo aparece como um elemento a mais de desconcentração do poder, por oferecer competência decisória às duas casas legislativas. Os países federativos são normalmente bicamerais, adotando a Câmara Alta como foro de representação das unidades territoriais ${ }^{11}$. Sistemas unicamerais são mais simples e com tendência majoritária; os sistemas bicamerais, como representam segmentos sociais diferenciados, enquadram-se dentro do modelo consensual. Argentina e Brasil são países federativos bicamerais. Uruguai é um país unitário, porém, bicameral.

a) Para Lijphart (2003), dois elementos são determinantes para tornar os sistemas bicamerais mais homogêneos ou mais divididos. Primeiro, o grau de congruência entre as duas câmaras, entendendo-se como bicameralismo congruente os sistemas eleitorais do mesmo tipo nas duas casas, porque isso facilita a constituição de corpos parlamentares mais homogêneos. Quando os sistemas são diferentes (incongruentes), cresce a possibilidade de vetos recíprocos. Nos três casos analisados, apenas o Uruguai adota o mesmo sistema (proporcional) nas duas eleições ${ }^{12}$. Na Argentina, a Câmara de Deputados é constituída pelo sistema proporcional e o Senado, por um sistema majoritário com correção proporcional (misto) ${ }^{13}$; no Brasil, o sistema eleitoral no Senado é majoritário e na Câmara de Deputados é proporcional (Colomer e Negretto, 2003). Estes são, portanto, incongruentes. 
b) O segundo fator crucial para definir a forma de bicameralismo, segundo Lijphart, é o grau de simetria entre as câmaras: são simétricas quando dotadas do mesmo nível de poder, e assimétricas quando uma detém mais poder que a outra. Segundo uma corrente de pesquisadores, uma forma de averiguar o nível de simetria é através dos impasses entre as duas casas. Caso sejam simétricas, a norma sobre os impasses nas votações é imparcial, não favorecendo a uma delas especificamente. Nesse caso, o poder é mais distribuído. Quando há uma hierarquia na solução de acordos, entende-se que as duas câmaras são assimétricas. Argentina e Brasil apresentam bicameralismos simétricos e o Uruguai dota a Câmara de Deputados de mais poderes, sendo considerada assimétrica $^{14}$.

c) Com base nesses elementos, Lijphart (2003) cria uma tipologia simples, que utilizo na tabela a seguir: "bicameralismo forte" ocorre quando há simetria e incongruência; "bicameralismo médio" é quando há uma simetria congruente ou uma assimetria incongruente; "bicameralismo fraco" é quando se combinam assimetria e congruência. À medida que o bicameralismo for mais forte, o país será mais consensual (e vice-versa).

4. É clássica na literatura política a análise dos efeitos dos sistemas eleitorais sobre a composição do Legislativo. A noção básica é que sistemas mais desproporcionais criam "maiorias fabricadas" que reduzem, de modo artificial, o número de partidos efetivos, já que as distorções sempre favorecem os maiores partidos. Quanto mais desproporcional for o sistema, mais majoritário ele será. Em relação ao Senado tem-se que:

a) O sistema eleitoral no Brasil elege senadores pelo voto majoritário, considerado dos mais desproporcionais. A Argentina adota um sistema majoritário com correção proporcional ${ }^{15}$. O tipo de sistema proporcional adotado pelo Uruguai leva a um nível alto de proporcionalidade (art. 95 e art. 96).

b) Desde o trabalho pioneiro de Rae (1967), também a magnitude do distrito tem sido apontada como significativamente responsável pelas distorções na representação. Quanto maior a magnitude, menor é o grau de distorção entre votos e cadeiras conquistadas pelos partidos. $\mathrm{Na}$ Argentina e Brasil, os distritos correspondem às unidades da federação, com três representantes por estado/província. Nos dois casos, trata-se, portanto, de uma magnitude baixa. O Uruguai, que não é país 
federativo, adota uma circunscrição única com 30 cadeiras, bastante proporcional (art. 94).

5.Para a Câmara dos Deputados (Câmara Baixa), todos os países da América Latina optam pelo sistema proporcional. Argentina e Brasil adotam os limites de circunscrição federativos (províncias e estados), oferecendo magnitudes de distrito responsáveis por considerável grau de distorção. No Uruguai, a Câmara de Representantes é constituída por meio de um distrito único nacional, com distribuição posterior aos departamentos, ou seja, utiliza um cálculo proporcionalmente muito mais exato ${ }^{16}$.

a) Cláusula de barreira, mecanismo utilizado para impedir que partidos com baixos percentuais de votos recebam cadeiras na Câmara de Deputados, é adotado apenas na Argentina, que exige dos partidos um mínimo de 3\% de votos nas províncias (Alcántara Sáez, García Montero e Sánches López, 2005a).

b) Na Argentina e Uruguai, a lista partidária é previamente fechada pelos partidos, enquanto no Brasil o sistema é de lista partidária com voto individualizado. Conforme ampla literatura, o nível de controle que o partido pode exercer sobre os parlamentares varia de acordo com o sistema. O sistema de lista fechada com indicação dos candidatos feita pelos partidos, tal como é adotado pela Argentina (e pela maioria dos países latino-americanos), favorece a centralização partidária. Embora o sistema uruguaio seja de listas fechadas, contém uma variação importante: os partidos apresentam sublistas (sublemas) com candidaturas diferentes, às quais são consideradas no cômputo proporcional de votos; esse sistema aumenta o grau de interferência do eleitor na escolha ${ }^{17}$. O sistema de listas com escolha individualizada, tal como existe no Brasil, incentiva o personalismo e um nível maior de dispersão partidária (Mainwaring e Shugart, 1999; Colomer e Negretto, 2003; Ames, 2003; Mainwaring, 2002).

c) Nenhum dos três países adota o sistema de reserva de cotas.

Argentina e Brasil apresentam vários componentes de um sistema consensual: ambos são federalistas, têm um bicameralismo forte e adotam o sistema eleitoral proporcional. Contudo, a Argentina apresenta no conjunto uma tendência à concentração de poder, principalmente porque o sistema eleitoral fortalece os partidos (pelo sistema de listas fechadas), favorece os partidos maiores (pelo tamanho dos distritos) e li- 
Presidencialismos em Perspectiva Comparada: Argentina, Brasil e Uruguai

Tabela 2

Dispersão do Poder e Sistema Político-Eleitoral

\begin{tabular}{|c|c|c|c|c|c|c|c|}
\hline Indicadores & Pesos & & Tipos & Ponto & Argentina & Brasil & Uruguai \\
\hline \multirow{6}{*}{$\begin{array}{l}\text { Eleições Pre- } \\
\text { sidenciais }\end{array}$} & \multirow{3}{*}{ Datas } & \multirow{3}{*}{1} & Únicas & 0 & & 0 & 0 \\
\hline & & & Datas mistas & 0,5 & 0,5 & & \\
\hline & & & Separadas & 1,0 & & & \\
\hline & \multirow{3}{*}{ Votos exigidos } & \multirow[t]{3}{*}{2} & Maioria simples & 0 & & & \\
\hline & & & Relativa & 0,5 & 0,5 & & \\
\hline & & & Absoluta & 1,0 & & 1,0 & 1,0 \\
\hline \multirow{6}{*}{ Estado } & \multirow{2}{*}{\begin{tabular}{|l} 
Unitário \\
Federativo
\end{tabular}} & 2 & Unitário & 0 & & & 0 \\
\hline & & & Federativo & 1,0 & 1,0 & 1,0 & \\
\hline & \multirow{4}{*}{$\begin{array}{l}\text { Unicameral } \\
\text { X } \\
\text { Bicameral }\end{array}$} & \multirow[t]{4}{*}{2} & Unicameral & 0 & & & \\
\hline & & & Bicameral fraco & 0,25 & & & 0,25 \\
\hline & & & Bicameral médio & 0,5 & & & \\
\hline & & & Bicameral forte & 1,0 & 1,0 & 1,0 & \\
\hline \multirow{5}{*}{$\begin{array}{l}\text { Sistema } \\
\text { Eleitoral } \\
\text { para Câmara } \\
\text { Alta }\end{array}$} & \multirow{2}{*}{$\begin{array}{l}\text { Magnitude do dis- } \\
\text { trito }\end{array}$} & 2 & Estadual/Provincial & 0 & 0 & 0 & \\
\hline & & & Nacional & 1,0 & & & 1,0 \\
\hline & \multirow{3}{*}{ Sistema eleitoral } & \multirow{3}{*}{2} & Majoritário & 0 & & 0 & \\
\hline & & & Misto & 0,5 & 0,5 & & \\
\hline & & & Proporcional & 1,0 & & & 1,0 \\
\hline \multirow{10}{*}{$\begin{array}{l}\text { Sistema } \\
\text { Eleitoral } \\
\text { para Câmara } \\
\text { Baixa }\end{array}$} & \multirow{3}{*}{$\begin{array}{l}\text { Magnitude do dis- } \\
\text { trito }\end{array}$} & 2 & Distrital & 0 & & & \\
\hline & & & Estadual/Provincial & 0,5 & 0,5 & 0,5 & \\
\hline & & & Nacional & 1,0 & & & 1,0 \\
\hline & \multirow{3}{*}{ Sistema eleitoral } & \multirow[t]{3}{*}{2} & Majoritário & 0 & & & \\
\hline & & & RP - Lista fechada & 0,5 & 0,5 & & 0,5 \\
\hline & & & $\begin{array}{l}\text { RP - Escolha indivi- } \\
\text { dual }\end{array}$ & 1,0 & & 1,0 & \\
\hline & \multirow{2}{*}{ Sistema de cotas } & \multirow{2}{*}{2} & Não & 0 & 0 & 0 & 0 \\
\hline & & & Sim & 1,0 & & & \\
\hline & \multirow{2}{*}{$\begin{array}{l}\text { Cláusula de } \\
\text { barreira }^{18}\end{array}$} & \multirow{2}{*}{2} & Sim & 0 & 0 & & \\
\hline & & & Não & 1,0 & & 1,0 & 1,0 \\
\hline \multicolumn{5}{|c|}{ Média Ponderada } & 0,45 & 0,58 & 0,60 \\
\hline
\end{tabular}

Fonte: Elaborada com base em Lijphart (2003); Anastasia, Melo e Santos (2004); Navarro (2004); Colomer e Negretto (2003); Alcántara Sáez, García Montero e Sánches López (2005a).

mita o número de partidos parlamentares (pela cláusula de barreira). O sistema eleitoral brasileiro é bem mais consensual. Por um lado, apresenta um efeito redutor nas eleições para o Senado (devido às distorções do sistema majoritário) e favorece os partidos maiores ao adotar como magnitude dos distritos os limites estaduais. Contudo, no Brasil, o sistema de lista com escolha individual e a ausência de cláusula de barreira indicam a existência de uma estrutura eleitoral sem influência sobre os partidos ${ }^{19}$. 
O Uruguai apresenta a maior tendência ao modelo consensual, com exigência de maioria absoluta nas eleições presidenciais, sistema bicameral e sistema eleitoral altamente proporcional. Mas a forma bicameral fraca (assimétrica e congruente), combinada ao voto partidário de lista fechada, fortalece o sistema. Além disso, o Uruguai é um país pequeno e bastante homogêneo, o que acarreta um nível bem menor de fragmentação partidária ${ }^{20}$.

\section{Estrutura Interna do Poder Legislativo}

Um segundo aspecto que interfere na composição legislativa (se mais fragmentada, ou mais homogênea) tem sido demonstrado em estudos recentes sobre a organização interna do Legislativo. Dois aspectos parecem relevantes nesta questão:

1. Primeiro, o modo como as comissões legislativas são organizadas. Em todos os países as comissões exercem um papel importante, havendo certo consenso de que sua atuação torna o trabalho do Legislativo mais profissionalizado, mais especializado (Alcántara Sáez, García Montero e Sánches López, 2005b). No entanto, elas podem ser estruturadas de modo bastante variado, e essas diferenças afetam a distribuição interna do poder (Anastasia, Melo e Santos, 2004):

a) As comissões compostas de acordo com a proporcionalidade partidária da casa legislativa tendem a apresentar um grau de diversidade muito maior do que as comissões compostas segundo outros critérios, como o princípio majoritário, a indicação do líder ou o sorteio. Havendo proporcionalidade partidária, a chance de as oposições participarem é maior. Brasil e Uruguai adotam esse sistema de escolha nas duas câmaras. Na Argentina, no Senado a escolha é partidária, mas na Câmara de Deputados é por designação do presidente. É claro que isso favorece muito o partido majoritário. Portanto, Brasil e Uruguai são mais consensuais.

b) O número de comissões em que cada parlamentar é obrigado a participar também interfere. O raciocínio, neste caso, é que o bom desempenho do trabalho está relacionado ao tempo que o parlamentar pode se dedicar ao estudo dos temas ligados à comissão. Um número muito elevado de comissões por parlamentar torna o trabalho completamente improdutivo. 
c) E a coincidência ou não entre as comissões do Legislativo e os ministérios do Executivo - se eles tratam dos mesmos assuntos - também influencia. Quando há paralelismo entre ministérios e comissões, supõe-se que o nível de interferência do Legislativo nos assuntos do Executivo tende a crescer, aumentando o equilíbrio na relação entre poderes.

2. O segundo aspecto para avaliar o nível de fragmentação legislativa é a existência ou não do Colégio de Líderes, prerrogativa institucional que atribui às lideranças partidárias a capacidade de centralizar grande parte do processo legislativo, enfraquecendo a possibilidade de intervenção da maioria da bancada. Uma linha interpretativa iniciada por Figueiredo e Limongi (1999) afirma que o Colégio de Líderes atua de forma combinada com o presidente da República, que utiliza seus "poderes de agenda" para controlar a produção legislativa. Sendo isso verdadeiro, a centralização propiciada pelo Colégio de Líderes favoreceria o Poder Executivo ${ }^{21}$. No Brasil e no Uruguai, o Colégio de Líderes existe somente na Câmara de Deputados. Na Argentina, há esse desenho nas duas casas legislativas. Mais uma vez, a Argentina é o país mais majoritário dentre os três.

A Tabela 3 mostra as diferenças nos três países. A Argentina une vários aspectos que favorecem a alta concentração de poder no Executivo. Brasil e Uruguai caracterizam-se pela descentralização, sendo o Uruguai nitidamente mais consensual.

\section{As Maiorias Especiais}

Nas democracias, normalmente as leis podem ser aprovadas ou alteradas no Legislativo com a simples maioria de votos, sendo algumas vezes exigida a maioria dos parlamentares presentes e algumas vezes um quorum mínimo. Mas em todas as constituições aparecem temas considerados mais importantes, que exigem maior consenso para aprovação. A determinação de que alguns temas exigem maiorias especiais aparece sempre, contudo, a delimitação de que assuntos são esses e de qual o percentual mínimo necessário de votos varia muito.

Na Tabela 4, os números das colunas representam a quantidade de artigos constitucionais que exigem algum tipo de maioria. Eles foram retirados do livro de Alcántara Sáez, García Montero e Sánches López (2005b), no estudo comparado sobre 18 países da América Latina. Com base nesses dados, a tabela estabelece pesos diferenciados de acordo 
Tabela 3

Dispersão do Poder e Processo Legislativo

\begin{tabular}{|c|c|c|c|c|c|c|}
\hline \multicolumn{3}{|l|}{ Indicadores } & \multirow{2}{*}{$\begin{array}{c}\text { Ponto } \\
1,0 \\
\end{array}$} & \multirow[t]{2}{*}{ Argentina } & \multirow{2}{*}{$\begin{array}{c}\text { Brasil } \\
1,0 \\
\end{array}$} & \multirow{2}{*}{$\begin{array}{c}\text { Uruguai } \\
1,0\end{array}$} \\
\hline \multirow{16}{*}{$\begin{array}{l}\text { Comissões } \\
\text { Peso } 1\end{array}$} & \multirow{3}{*}{$\begin{array}{l}\text { Como são } \\
\text { constituídas }\end{array}$} & 2 Câmaras partidárias & & & & \\
\hline & & 1 Câmara partidária & 0,5 & 0,5 & & \\
\hline & & Outra forma & 0 & & & \\
\hline & \multirow{5}{*}{$\begin{array}{l}\text { Comissões } \\
\text { por deputado }\end{array}$} & $1-2$ & 1,0 & & 1,0 & 1,0 \\
\hline & & $2-3$ & 0,75 & 0,75 & & \\
\hline & & $3-4$ & 0,5 & & & \\
\hline & & $4-5$ & 0,25 & & & \\
\hline & & + de 5 & 0 & & & \\
\hline & \multirow{5}{*}{$\begin{array}{l}\text { Comissões } \\
\text { por senador }\end{array}$} & $1-2$ & 1,0 & & 1,0 & \\
\hline & & $2-3$ & 0,75 & & & 0,75 \\
\hline & & $3-4$ & 0,5 & & & \\
\hline & & $4-5$ & 0,25 & & & \\
\hline & & + de 5 & 0 & 0 & & \\
\hline & \multirow{3}{*}{$\begin{array}{l}\text { Relação entre } \\
\text { Ministérios e } \\
\text { Comissões }\end{array}$} & Baixa & 0 & & 0 & \\
\hline & & Média & 0,5 & 0,5 & & \\
\hline & & Alta & 1,0 & & & 1,0 \\
\hline \multirow{3}{*}{\multicolumn{2}{|c|}{ Colégio de Líderes Peso 4}} & Não há & 1,0 & & & \\
\hline & & 1 Câmara & 0,5 & & 0,5 & 0,5 \\
\hline & & 2 Câmaras & 0 & 0 & & \\
\hline \multicolumn{3}{|c|}{ Média Ponderada } & & 0,22 & 0,62 & 0,72 \\
\hline
\end{tabular}

Fonte: Elaborada com base em Anastasia, Melo e Santos (2004).

com a maioria exigida: quanto mais amplas as maiorias, maior é o peso. A idéia subjacente é que, aumentando o número de votos necessários, cresce a necessidade de consenso e, portanto, maior é a dificuldade em alterar a situação. Como afirma Tsebelis (1997:100), "raramente se verifica uma exigência constitucional de maiorias qualificadas. Mas, onde quer que ela exista e sempre que isso ocorrer, tal exigência conferirá poder de veto a determinadas coalizões de atores e, portanto, aumentará a estabilidade do status quo".

Entre os países aqui analisados, vê-se que a legislação argentina impõe menos obstáculos às mudanças: são seis os casos que exigem maioria absoluta e dois os que exigem $2 / 3$ dos presentes. Uma única vez a constituição argentina exige maioria de $2 / 3$ do total de deputados da Câmara; trata-se exatamente da mudança constitucional (art. 30). Mais uma vez, a Constituição argentina tende ao modelo concentrador de poder. 
No caso do Brasil, o número de artigos que exige maioria qualificada é maior, com sete situações determinando maioria absoluta dos membros da casa. A emenda constitucional exige maioria qualificada de $3 / 5$ da Câmara e cinco casos estabelecem uma maioria de 2/3. Entretanto, a situação mais emblemática é a do Uruguai, que aparece como o país latino-americano que apresenta maiores empecilhos às mudanças de regra entre todos os países da América Latina. Em virtude disso, o caso uruguaio foi arbitrariamente definido como de máxima desconcentração (valor 1,0) na tabela.

Tabela 4

Dispersão de Poder em Relação à Exigência de Maiorias*

\begin{tabular}{l|c|c|c|c}
\hline Maioria Exigida $^{22}$ & Peso & Argentina & Brasil & Uruguai \\
\hline Maioria absoluta & 1 & 6 & 7 & 6 \\
3/5 da Câmara & 2 & 0 & 1 & 17 \\
2/3 dos presentes & 3 & 0 & 2 & 9 \\
2/3 da Câmara & 4 & 1 & 5 & 5 \\
3/4 dos presentes & 5 & 0 & 0 & 0 \\
\hline Média Ponderada** $^{*}$ & & $\mathbf{0 , 1 1}$ & $\mathbf{0 , 4 0}$ & $\mathbf{1 , 0}$ \\
\hline
\end{tabular}

Fonte: Elaborada com base em García Montero (2004, Tabela 9).

* Em números absolutos dos artigos constitucionais que exigem a maioria da linha.

** O Uruguai foi considerado valor 1, pois é o país da América Latina que mais apresenta exigências constitucionais. Os outros valores obedecem à proporção com base na média ponderada.

\section{Status de Constitucionalidade}

Considerando-se, como foi feito anteriormente, que a exigência de maioria qualificada dificulta a a provação de normas, deve-se salientar que as normas constitucionais estão entre as que apresentam os maiores níveis de dificuldade, pois é normal em todos os países a exigência de ampla maioria para aprovação de emendas à Constituição. Sendo assim, quanto mais volumosas e detalhadas forem as constituições, maior é a quantidade de temas difíceis de serem modificados.

A Constituição brasileira apresenta um total de 250 artigos. No Brasil, a emenda à Constituição pode ser proposta pelo presidente da República, por 1/3 da Câmara dos Deputados ou Senado ou por mais de $50 \%$ das assembléias legislativas. Deve ser discutida em dois turnos nas duas casas e a aprovação exige $3 / 5$ dos votos de cada casa, em cada votação (art. 60). Ela contém inúmeras questões tratadas em detalhes a 
respeito de temas sociais e econômicos. A pesquisa sistemática em seus 250 artigos mostra que 13 questões recebem tratamento minucioso.

Durante a década de 1990, várias emendas constitucionais no Brasil alteraram artigos relativos às empresas estatais e à proteção ao capital nacional, modificando o perfil nacionalista da carta de 1988. Entretanto, muitos artigos relacionados à economia permaneceram, bem como a extensa lista de direitos individuais, políticos e sociais. Isso significa que, para ocorrer qualquer mudança nesses assuntos, é necessário um consenso muito alto.

A Constituição uruguaia, com um total de 332 artigos, faz exigências ainda maiores para emendas constitucionais. Para iniciar um projeto de reforma, é necessário ou a assinatura da maioria absoluta dos membros da Assembléia Geral, ou a assinatura de 10\% dos eleitores uruguaios, ou a assinatura de $2 / 5$ da Assembléia, que solicitarão um plebiscito. A aprovação de emenda exige uma maioria de $2 / 3$ da Assembléia (art. 331). A Constituição uruguaia igualmente apresenta inúmeros temas sociais, políticos e econômicos - tratados de forma detalhada.

A característica mais nítida da Constituição uruguaia é a defesa dos organismos estatais. Direitos individuais, da família e da educação também aparecem aqui, mas o que se destaca nela é a ampla regulamentação dos serviços estatais, dos monopólios do Estado e da política industrial. Também ela passou por várias emendas constitucionais durante a década de 1990 e uma profunda reforma em 1996, mas esse caráter nacionalista permaneceu.

A Constituição argentina em vigor é fruto da reforma de 1994. Diferentemente das constituições brasileira e uruguaia, tem apenas 129 artigos e apenas três temas (sociais) tratados de forma constitucional. Para ser reformada, a emenda constitucional deve ser proposta por 2/3 do Congresso, percentual bastante alto (art. 30). Entretanto, como são poucas as questões substantivas inseridas no texto, simples maioria é suficiente para aprovar esse tipo de norma.

A Tabela 5 atribui valor máximo ao Brasil $($ valor 1,0$)$ e valor mínimo à Argentina (valor 0). O Uruguai também se coloca como bastante consensual. 
Presidencialismos em Perspectiva Comparada: Argentina, Brasil e Uruguai

Tabela 5

Dispersão de Poder nas Questões Constitucionalizadas ${ }^{23}$

\begin{tabular}{l|c|c|c|c}
\hline Indicadores & Ponto & Argentina & Brasil & Uruguai \\
\hline 13 ou + questões & 1,0 & & 1,0 & \\
Entre 10-12 questões & 0,75 & & & 0,75 \\
Entre 7-9 questões & 0,5 & & & \\
Entre 4-6 questões & 0,25 & & & \\
Até 3 questões & 0 & 0 & $\mathbf{1 , 0}$ & $\mathbf{0 , 7 5}$ \\
\hline Resultado
\end{tabular}

Fontes: Elaborada com base em Constitución de la República Oriental del Uruguay; Constituição da República Federal do Brasil; Constitución de la Nación Argentina

\section{Mecanismos de Accountability Horizontal ${ }^{24}$}

Uma das funções clássicas do Estado liberal é o controle recíproco entre poderes e, sendo assim, todas as constituições democráticas procuram dotar o Legislativo com alguns desses mecanismos. Os indicadores da Tabela 6 seguem a teoria de Alcántara Sáez, García Montero e Sánches López (2005b) de que o controle parlamentar é uma atividade essencialmente política que abrange várias instâncias. Uma primeira estaria situada no campo simbólico, ocorrendo a partir do momento em que os problemas governamentais passam a ser objeto de debates e informações dentro do Legislativo. Por exemplo, a publicidade própria da ação parlamentar já se apresenta como uma forma de accountability.

Entretanto, há um segundo patamar em que o Legislativo adquire poder de fato. Isso acontece quando ele se encontra municiado de prerrogativas legais para impor sanções efetivas ao governo. A Tabela 6 procura quantificar esses dois níveis (simbólico e de fato) nos três países da América Latina. Para tanto, considera os seguintes aspectos:

1. O comparecimento ao Legislativo de ministros e altos funcionários do Executivo, com o objetivo de prestar informações, está previsto em todas as constituições da América Latina. Mas poucas, Brasil entre elas, impõem sanções pelo não-comparecimento (art. 50).

2. Uma das formas usuais de fiscalização do Legislativo é por meio da solicitação de informes. O que varia nesse caso é a existência ou não de penalidades pelo descumprimento do pedido. Dentre os 18 países da América Latina, apenas cinco estabelecem algum tipo de punição: Bolívia, Brasil, Chile, Colômbia e Peru. 
3. A possibilidade da Comissão Parlamentar de Inquérito - CPI existe nos legislativos da Argentina, Brasil e Uruguai. As CPIs são elementos simbólicos importantes de controle, nas quais parlamentares, funcionários do governo e pessoas que se envolvem em situações comprometedoras para a ordem pública são questionados e confrontados.

4. Muito mais efetivo, porém, do que o questionamento é a possibilidade de acesso a contas bancárias e telefônicas dos investigados. Isso acontece quando há direito legislativo de investigação judicial, como no Brasil (art. 58, §3으).

5. Em todos os países latino-americanos, o presidente da República vai anualmente ao Congresso para informar sobre seu plano de governo e prestar contas de sua administração. Os modos como isso acontece são variados, mas um fator determinante para o controle simbólico do Legislativo é a possibilidade de os parlamentares pronunciarem-se diante da exposição do presidente. Os legislativos do Brasil, Argentina e Uruguai limitam-se a ouvir, sem direito a questionamentos.

6. A interpelação é um mecanismo em que ministros e funcionários do Poder Executivo comparecem para prestar informações e ser questionados pelos parlamentares. Em seguida há um debate em plenário e uma votação. Segundo Alcántara Sáez, García Montero e Sánches López (2005b), 14 dos 18 países adotam essa medida. Em geral, essa votação tem o efeito simbólico de dar publicidade aos acontecimentos, sem acarretar penalidades específicas. Mas em determinadas democracias a interpelação pode levar a uma moção de censura.

7. A moção de censura é um mecanismo típico dos sistemas parlamentaristas, prevista na Constituição de 13 democracias presidencialistas latino-americanas. Contudo, na grande maioria dos casos ela tem um efeito meramente simbólico, já que o Legislativo não possui autorização de fato para destituir ministros. O Brasil não adota essa medida. Argentina (art. 101) e Uruguai (art. 147), sim.

8. Uma segunda possibilidade, bem mais rara nos sistemas presidencialistas, é que o Legislativo tenha poder legal de destituir ministros. Apenas três se encontram nessa condição: Argentina (para o chefe de gabinete, art. 101), Uruguai (art. 148) e Venezuela (art. 246).

9. Outra medida de caráter claramente parlamentarista é o Voto de Confiança, que existe nas constituições do Peru (art. 130) e do Uruguai (art. 148). No Uruguai, se os ministros forem reprovados pelo Legislativo por um percentual inferior a 2/3 da Assembléia Geral, o presiden- 
te da República tem o direito de pedir um voto de confiança. Caso este não seja dado, ele pode dissolver o Legislativo e convocar novas eleições. Se a censura for dada por um percentual superior a $2 / 3$ da Assembléia Geral, o presidente da República é obrigado a aceitá-la.

10. O julgamento, com possibilidade de exoneração de funcionários, ministros, vice-presidente e presidente da República, é um caso extremo de controle, que demanda um processo árduo e desgastante. Mas há diferenças entre os motivos que permitem a abertura do processo. Segundo Alcántara Sáez, García Montero e Sánches López (2005b), sete motivos são considerados nas constituições. Com base nesses dados, a Tabela 6 reduziu essas possibilidades para três, creio que sem prejuízo da análi$\mathrm{se}^{25}$. A primeira possibilidade de impeachment é por crime comum.

Tabela 6

Níveis de Controle do Legislativo sobre o Executivo

\begin{tabular}{l|c|c|c}
\hline Indicadores* & Argentina & Brasil & Uruguai \\
\hline $\begin{array}{l}\text { Sanções pelo não-comparecimento de ministros e } \\
\text { altos funcionários para prestar contas }\end{array}$ & 0 & 1,0 & 0 \\
\hline $\begin{array}{l}\text { Penalidades por não apresentar as informações so- } \\
\text { licitadas pelo Legislativo }\end{array}$ & 0 & 1,0 & 0 \\
\hline Possibilidade de criar CPIs & 1,0 & 1,0 & 1,0 \\
\hline CPIs com poderes judiciais & 0 & 1,0 & 0 \\
\hline $\begin{array}{l}\text { Pronunciamentos do Parlamento sobre informes } \\
\text { do presidente da República }\end{array}$ & 0 & 0 & 0 \\
\hline Interpelação a ministros e altos funcionários & 1,0 & 0 & 1,0 \\
\hline Censura a ministros & 1,0 & 0 & 1,0 \\
\hline Censura vinculante & 1,0 & 0 & 1,0 \\
\hline Voto de Confiança & 0 & 0 & 1,0 \\
\hline Impeachment por crime comum & 1,0 & $0,5 * *$ & 1,0 \\
\hline Impeachment por crime de responsabilidade & 1,0 & 1,0 & 1,0 \\
\hline Impeachment por mau desempenho & 1,0 & 0 & 0 \\
\hline Média & $\mathbf{0 , 5 8}$ & $\mathbf{0 , 4 6}$ & $\mathbf{0 , 5 8}$ \\
\hline
\end{tabular}

Fonte: Elaborada com base em Alcántara Sáez, García Montero e Sánches López (2005b).

* Sim: 1,0; Não: 0 .

** No Brasil, a Câmara dos Deputados pode iniciar processo por crime comum, mas os resultados são enviados ao Supremo Tribunal Federal, que efetua o julgamento. Portanto, a punição foge da esfera legislativa. 
11. A segunda possibilidade de impeachment é por crime de responsabilidade.

12. A terceira é por mau desempenho. Nos três casos o processo se desenvolve na Câmara e, sendo aprovado por $2 / 3$ da casa, passa para o Senado, onde será julgado.

Na Tabela 6, o Brasil aparece como o país mais centralizador ${ }^{26}$, sobretudo porque não adota os mecanismos de "tipo parlamentarista".

\section{Intervenção do Legislativo no Plano Orçamentário}

O projeto orçamentário é uma das mais importantes peças para desenvolvimento das políticas de governo, visto que é o orçamento que determina como serão aplicados os recursos do Estado, estabelecendo as áreas prioritárias e os montantes a serem despendidos. Trata-se de uma das legislações de caráter mais conflituoso, que envolve disputas no interior do próprio Poder Executivo, dentro do Legislativo e entre os dois Poderes.

Alcántara Sáez, García Montero e Sánches López (2005b) analisaram a legislação de 18 países latino-americanos, mostrando que é sempre o Poder Executivo que elabora o plano orçamentário ${ }^{27}$ e o envia ao Legislativo para que seja analisado, emendado e aprovado. A possibilidade que o Legislativo tem de interferir, modificando o projeto original, é diversa na América Latina, sendo considerados fatores de maior influência os seguintes pontos:

1. se há possibilidade de o Legislativo iniciar o projeto orçamentário;

2. se há proibição expressa para o Executivo utilizar o mecanismo da delegação;

3. se há proibição expressa para o Executivo utilizar o mecanismo do pedido de urgência;

4. qual o tempo de tramitação legalmente estabelecido;

5. qual a possibilidade de o Legislativo modificar o projeto orçamentário;

6. qual a possibilidade de o Executivo fazer gastos sem autorização (havendo essa brecha, obviamente, o Poder Executivo é fortalecido);

7. qual a solução legal em caso de rejeição ou não-aprovação do projeto. Em alguns casos, o Executivo é favorecido, em outros, é o Legislativo. 
8. se há proibição de veto do Executivo nessa matéria.

No texto citado, os autores lembram que há duas características constitucionais importantes na legislação orçamentária que se encontram presentes, sob medidas variadas, nos diversos países da América Latina: a primeira é que durante a década de 1990, em razão das mudanças econômicas ocorridas no capitalismo internacional, houve uma tendência em privilegiar o controle fiscal na legislação orçamentária; a segunda é que várias constituições estabelecem percentuais fixos de gastos com determinados setores, enrijecendo a lei de orçamento.

Esses aspectos devem ser levados em conta, uma vez que são características constitucionais que refletem duas tendências politicamente opostas: uma é fruto da política predominante durante a década de 1990; e a outra apresenta um caráter claramente social-democrata, ideologia com forte influência em um período anterior. Observando-se as constituições da Argentina, Brasil e Uruguai, nota-se que elas assimilaram, de modos diferenciados, essas duas tendências, que apresentam conseqüências importantes para a questão da concentração ou dispersão do poder decisório.

A Constituição brasileira é de 1988, momento da democratização em que variados grupos de esquerda tiveram influência para redigir uma carta de direitos. Por esse motivo, aparecem vários artigos vinculando o orçamento a gastos sociais: as quotas despendidas para educação (art. 212), saúde (art. 198, § 2ㅇ) e funcionalismo (art. 37, XXII) encontram-se constitucionalmente garantidas. Vinculado a isso, a Constituição estabeleceu o modelo descentralizado e socialmente participativo da gestão da saúde e educação, com a regulamentação dos "conselhos". Em muitos aspectos, a Constituição brasileira cerceia a autonomia do Executivo em relação à política orçamentária. Entretanto, a Constituição brasileira faz muitas restrições à possibilidade de parlamentares inserirem emendas ao projeto enviado pelo Executivo. $\mathrm{O}$ art. 167 da Constituição define "que as despesas não podem exceder os créditos orçamentários" e que fazer investimentos sem autorização prévia da lei implica crime de responsabilidade (passível de impeachment).

A Constituição uruguaia é de 1967. Não há artigos que predeterminem despesas de cunho social. Mas também no Uruguai a década de 1990 trouxe mudanças constitucionais com o objetivo de controlar o déficit orçamentário (art. 215 e art. 225). Assim, a Constituição uruguaia mantém a tendência predominante em toda a América Latina, que é fortale- 
cer o Executivo nessa questão. Mas nesse país a legislação apresenta uma originalidade, ao colocar no centro da elaboração do projeto orçamentário a "Oficina de Planeamiento y Presupuesto", composta por segmentos da sociedade (representantes de trabalhadores e de empresas públicas e privadas). Conquanto o orçamento esteja vinculado à burocracia técnico-executiva, há um mecanismo que estimula a participação da sociedade.

A nova Constituição argentina foi elaborada em 1994, durante a era Menem. É a constituição mais enxuta; ela apresenta poucos artigos relativos ao orçamento e envia todas as especificidades para a legislação ordinária. Desse modo, o problema do déficit financeiro não aparece no texto constitucional. Pelo contrário, o art. 75, 9 da Constituição argentina diz que cabe ao Congresso determinar os subsídios do tesouro para as províncias "cujas rendas não atinjam, segundo seus orçamentos, os gastos ordinários". O que está determinado vai de encontro à idéia de controle fiscal, sendo uma norma com sentido oposto ao da chamada "lei de responsabilidade fiscal", predominante na América Latina a partir da década de 1990. Como gasto fixo, a constituição determina que uma "lei convênio" estabelecerá um acordo entre nação e províncias, instituindo uma parcela automática de contribuição direta (art. 75, 2).

A Tabela 7, referente ao processo orçamentário, mostra que o poder no Brasil e Uruguai é mais concentrado. A Argentina fica na posição intermediária, impondo menos restrições ao Legislativo.

\section{OS PODERES LEGISLATIVOS DO EXECUTIVO}

Finalmente, a última questão a ser mensurada são os mecanismos proativos e reativos sob controle do presidente da República. Estas são normas que não apresentam a possibilidade de dispersão de poder, visto que, claramente, têm por objetivo fortalecer o presidente da República. Vejamos:

\section{Iniciativa Legislativa Exclusiva}

A participação do Executivo na elaboração das leis tem sido apontada como um dos indicadores da força do presidente da República no mundo atual. O Executivo pode enviar projetos de lei que tramitam normalmente no Congresso Nacional ${ }^{28}$, entretanto, conforme lembram Colomer e Negretto (2003:36), “a iniciativa ordinária não confere, por si só, 
Presidencialismos em Perspectiva Comparada: Argentina, Brasil e Uruguai

Tabela 7

Lei Orçamentária e Concentração do Poder Decisório

\begin{tabular}{|c|c|c|c|c|c|}
\hline \multicolumn{2}{|l|}{ Indicadores } & \multirow{3}{*}{\begin{tabular}{c|} 
Ponto \\
1,0 \\
0
\end{tabular}} & \multirow{3}{*}{$\begin{array}{c}\text { Argentina } \\
\\
0\end{array}$} & \multirow{3}{*}{\begin{tabular}{c|} 
Brasil \\
0 \\
0
\end{tabular}} & \multirow{3}{*}{$\begin{array}{c}\text { Uruguai } \\
0 \\
0\end{array}$} \\
\hline Legislativo pode iniciar o pro- & Sim & & & & \\
\hline jeto orçamentário & Não & & & & \\
\hline \multirow{2}{*}{$\begin{array}{l}\text { Proibição de o Executivo utili- } \\
\text { zar delegação para projeto or- } \\
\text { çamentário }\end{array}$} & Sim & 1,0 & \multirow[t]{2}{*}{1,0} & \multirow[t]{2}{*}{1,0} & \multirow[t]{2}{*}{$1,0^{*}$} \\
\hline & Não & 0 & & & \\
\hline \multirow{2}{*}{$\begin{array}{l}\text { Proibição de o Executivo utili- } \\
\text { zar pedido de urgência }\end{array}$} & Sim & 1,0 & \multirow[t]{2}{*}{$1,0 * *$} & \multirow[b]{2}{*}{0} & \multirow[t]{2}{*}{1,0} \\
\hline & Não & 0 & & & \\
\hline \multirow[t]{4}{*}{ Tempo de tramitação } & - de 2 meses & 0 & \multirow{4}{*}{$1,0^{* * *}$} & \multirow{4}{*}{$\begin{array}{r}1,0 \\
-0,5\end{array}$} & \multirow{4}{*}{$\begin{array}{r}1,0 \\
-0,5\end{array}$} \\
\hline & Entre 2 e 3 & 0,5 & & & \\
\hline & +3 meses & 1,0 & & & \\
\hline & Bicameral ${ }^{* * * *}$ & $-0,5$ & & & \\
\hline \multirow{4}{*}{$\begin{array}{l}\text { Possibilidade de o Legislativo } \\
\text { modificar o projeto }\end{array}$} & Não pode & 0 & & \multirow{4}{*}{0,25} & \multirow{4}{*}{0,25} \\
\hline & Só remanejar & 0,25 & & & \\
\hline & Com restrições & 0,5 & & & \\
\hline & Sem restrições & 1,0 & 1,0 & & \\
\hline \multirow{4}{*}{$\begin{array}{l}\text { Possibilidade de o Executivo } \\
\text { fazer gastos sem autorização }\end{array}$} & É punido & 1,0 & \multirow{4}{*}{0} & \multirow[t]{4}{*}{1,0} & \multirow{4}{*}{0} \\
\hline & Não pode & 0 & & & \\
\hline & Sim, em casos extraordinários & $-0,5$ & & & \\
\hline & Não há empecilho & $-1,0$ & & & \\
\hline \multirow{3}{*}{$\begin{array}{l}\text { Qual a solução em caso de re- } \\
\text { jeição ou não aprovação }\end{array}$} & Não há previsão & 0 & \multirow{3}{*}{0,5} & \multirow[t]{3}{*}{0} & \multirow{3}{*}{0,5} \\
\hline & Manter a anterior & 0,5 & & & \\
\hline & Não pode executar & 1,0 & & & \\
\hline \multirow[t]{2}{*}{ Executivo sem poder de veto } & Sim & 1,0 & \multirow[b]{2}{*}{0} & \multirow[b]{2}{*}{0} & \\
\hline & Não & & & & 0 \\
\hline Percentuais de gastos sociais & Não há & 0 & & & 0 \\
\hline fixos & Um setor & 0,5 & 0,5 & & \\
\hline & Dois setores & 0,75 & & & \\
\hline & Três setores & 1,0 & & 1,0 & \\
\hline Participação de segmentos da & Sim & 1,0 & & & 1,0 \\
\hline sociedade na elaboração & Não & 0 & 0 & 0 & \\
\hline Média & & & 0,5 & 0,37 & 0,42 \\
\hline
\end{tabular}

Fonte: Elaborada com base em Alcántara Sáez, García Montero e Sánches López (2005b).

*Não há lei delegada no Uruguai.

** Não há pedido de urgência na Argentina.

*** A Constituição argentina não estipula prazo de tramitação.

**** A discussão nas duas casas divide o tempo disponível entre ambas e, nesse caso (seguindo a sugestão de Alcántara Sáez, García Montero e Sánches López), foi diminuído 0,5 ponto. 
nenhuma vantagem. Se o Congresso pode modificar livremente a proposta presidencial (ou mesmo não considerá-la) cabe esperar que os resultados sejam muito parecidos aos obtidos pela iniciativa congressu$\mathrm{al}^{\prime \prime}$. Em muitos casos, como nos projetos de lei ordinária ou emendas constitucionais, a participação do Legislativo é intensa durante o período de tramitação da matéria. O Legislativo participa, propondo emendas e muitas vezes conseguindo alterar substancialmente o projeto original.

A capacidade de interferência do presidente da República é efetivamente aumentada com a perspectiva da iniciativa exclusiva. Sem dúvida, também esses projetos podem ser completamente alterados no processo de tramitação, mas neste caso cabe ao Executivo determinar os termos e o momento da apresentação do projeto. Isso lhe confere um considerável grau de controle, sobretudo quando pretende manter o status quo, deixando de enviar a proposta.

O número de normas cuja iniciativa cabe exclusivamente ao presidente da República é bastante alto na América Latina, encontrando-se relacionado fundamentalmente aos artigos referentes à política econômica e financeira (Colomer e Negretto, 2003). A Tabela 8 relaciona os temas em que o Executivo detém a exclusividade, mostrando que há diferenças entre os três países.

No Brasil, além da questão econômica e financeira, observa-se que a Constituição mantém sob controle do Executivo a administração federal, e alguns temas específicos, como atividade nuclear. A iniciativa exclusiva é um dos requisitos que mais fortemente favorecem o presidente da República no Brasil, indicando alto grau de concentração do poder.

No Uruguai, essas normas dizem respeito à gestão da economia e às questões que envolvem gastos públicos. O Uruguai não adota o decreto de necessidade e urgência nem a lei delegada, amenizando muito a tendência à concentração do poder nesta questão da iniciativa. A Argentina mostra-se bem menos centralizadora neste aspecto, apresentando um número mediano de iniciativas exclusivas.

\section{Veto presidencial}

Nos sistemas presidencialistas, o veto é uma modalidade comum de intervenção do presidente da República sobre o processo legislativo, 
Presidencialismos em Perspectiva Comparada: Argentina, Brasil e Uruguai

Tabela 8

Temáticas de Iniciativa Legislativa Exclusiva do Presidente da República

\begin{tabular}{|c|c|c|c|c|}
\hline Indicadores & Ponto* & Argentina & Brasil & Uruguai \\
\hline \multirow[t]{2}{*}{ Sistema tributário } & 0 & & 0 & 0 \\
\hline & 1 & 1,0 & & \\
\hline \multirow[t]{2}{*}{ Salário mínimo } & 0 & & & 0 \\
\hline & 1 & 1,0 & 1,0 & \\
\hline \multirow{2}{*}{$\begin{array}{l}\text { Projetos que envolvem gastos públicos e } \\
\text { aquisição de produtos }\end{array}$} & 0 & & & 0 \\
\hline & 1 & 1,0 & 1,0 & \\
\hline \multirow{2}{*}{$\begin{array}{l}\text { Plano anual de governo e orçamento } \\
\text { anual }\end{array}$} & 0 & 0 & 0 & 0 \\
\hline & 1 & & & \\
\hline \multirow[t]{2}{*}{ Organização de cargos administrativos } & 0 & 0 & 0 & \\
\hline & 1 & & & 1,0 \\
\hline \multirow{2}{*}{$\begin{array}{l}\text { Aumentos de salários a funcionários e } \\
\text { aposentados. }\end{array}$} & 0 & & 0 & 0 \\
\hline & 1 & 1,0 & & \\
\hline \multirow[t]{2}{*}{ Fixar e organizar as Forças Armadas } & 0 & 0 & 0 & 0 \\
\hline & 1 & & & \\
\hline \multirow[t]{2}{*}{ Legislação sobre atividades nucleares } & 0 & & 0 & \\
\hline & 1 & 1,0 & & 1,0 \\
\hline \multirow{2}{*}{$\begin{array}{l}\text { Decretos de necessidade e urgência (Me- } \\
\text { didas Provisórias) }\end{array}$} & 0 & 0 & 0 & \\
\hline & 1 & & & 1,0 \\
\hline \multirow[t]{2}{*}{ Lei delegada } & 0 & 0 & 0 & \\
\hline & 1 & & & 1,0 \\
\hline \multirow{2}{*}{$\begin{array}{l}\text { Criação e organização de ministérios e } \\
\text { órgãos da administração pública }\end{array}$} & 0 & 0 & 0 & 0 \\
\hline & 1 & & & \\
\hline \multirow{2}{*}{$\begin{array}{l}\text { Organização do Ministério Público e De- } \\
\text { fensoria da União }\end{array}$} & 0 & & 0 & \\
\hline & 1 & 1,0 & & 1,0 \\
\hline Média & & 0,50 & 0,17 & 0,42 \\
\hline
\end{tabular}

Fonte: Elaborada com base em Constitución de la República Oriental del Uruguay; Constituição da República Federal do Brasil e Constitución de la Nación Argentina.

* Sim: 0; Não: 1,0. 
aparecendo em constituições de 18 países da América Latina (García Montero, 2004). Essa medida encontra-se presente também na Constituição dos Estados Unidos, sendo considerada naquele país a forma de controle mais importante do Executivo sobre os trabalhos do Congresso (Molinelli, 1991).

As normas sobre o veto apresentam variações de um país para outro. Sempre é estabelecido um prazo para que o presidente se pronuncie sobre a lei aprovada no Legislativo. Mas, o mais importante para medir o grau de controle do Executivo são os procedimentos reguladores do veto, assim como os da sua derrubada (insistencia):

a) Na grande maioria dos casos, além dos vetos integrais, também são aceitos os vetos parciais.

b) Quanto aos procedimentos de derrubada do veto, é claro que tanto o poder Executivo será mais forte quanto mais dificultoso for derrubá-lo. Nesse caso, duas regras influenciam: primeira, se as duas casas legislativas atuam de modo conjunto ou separado (exigir a decisão em cada casa, separadamente, é uma forma de dificultar a derrubada); segunda, o número de votos parlamentares necessários, exigindo-se desde a maioria absoluta dos membros da casa até a maioria de $2 / 3$ dos membros da casa.

A Tabela 9 estabelece pontos diferenciados de acordo com a dificuldade envolvida no processo de derrubada do veto presidencial. A Argentina impõe sérias restrições à autonomia do Legislativo: aceita o veto integral e parcial (art. 80 a 83) e, para que ele seja derrubado, é necessário que passe pelas duas câmaras separadamente e seja aprovado por uma maioria de $2 / 3$ dos presentes. Em resumo, há poucas possibilidades de que seja derrubado e, nesse sentido, apresenta um caráter fortemente concentrador de poder.

Brasil (art. 66, § 1으) e Uruguai (art. 137 e art. 138) admitem o veto integral e parcial e definem que a decisão para derrubada deve dar-se em assembléia conjunta das duas casas. A maioria exigida é mais expressiva no Uruguai ( $3 / 5$ dos presentes) do que no Brasil (maioria absoluta). O veto é, portanto, um mecanismo importante para fortalecer o Executivo nestes dois países. 
Tabela 9

Veto Presidencial

\begin{tabular}{l|l|c|c|c|c}
\hline \multicolumn{2}{l|}{ Indicadores } & Ponto & Argentina & Brasil & Uruguai \\
\hline \begin{tabular}{l|l} 
Veto \\
(Peso 2)
\end{tabular} & Não há veto & 1,0 & & & \\
& Só veto integral & 0,5 & & & \\
& Parcial e integral & 0 & 0 & 0 & 0 \\
\hline $\begin{array}{l}\text { Derrubada } \\
\text { (Peso 1) }\end{array}$ & Não há veto & 1,0 & & & \\
& Pela Assembléia & 0,5 & & 0,50 & 0,50 \\
Maioria p/ & Pela CO e CR* & 0 & 0 & & \\
$\begin{array}{l}\text { derrubada } \\
\text { Peso 1) }\end{array}$ & Não há veto & 1,0 & & & \\
& Maioria absoluta & 0,75 & & 0,75 & \\
\hline Média Ponderada dos presentes & 0,50 & & & 0,50 \\
\hline
\end{tabular}

Fontes: Elaborada com base em García Montero (2004); Alcántara Sáez, García Montero e Sánches López (2005a; 2005b); Constitución de la República Oriental del Uruguay; Constituição da República Federal do Brasil e Constitución de la Nación Argentina.

* Câmara de Origem - Câmara Revisora.

\section{Pedido de Urgência}

Essa norma aparece em seis países sul-americanos ${ }^{29}$, sendo que alguns oferecem mais do que uma modalidade de urgência. No Chile, por exemplo, há o pedido de urgência simples, com 30 dias de prazo, a suma urgência, com 10 dias, e a discussão imediata, com prazo de três dias (art. 49).

O pedido de urgência é um poderoso recurso do presidente da República que, ao solicitá-lo, encurta prazos de discussão, reduzindo os debates e tornando muito mais provável a possibilidade de aprovação de seu projeto tal como foi enviado. Ele não anula a tramitação, nem a possibilidade de rejeição e de modificação da matéria, mas pelo fato de encurtar os prazos, limita a possibilidade de mudança. Há muitas diferenças entre as legislações, havendo em alguns países um controle mais forte do Executivo. Analisando-se essas possibilidades, alguns fatores parecem fundamentais:

a) se há limitação no prazo de envio ou se o Executivo pode fazer a solicitação em qualquer momento da tramitação do projeto; 
b) se os prazos para análise da matéria são minimamente aceitáveis, ou se são muito curtos, impedindo a interferência do Legislativo na decisão;

c) se há restrições nas temáticas, ou o presidente da República pode solicitar urgência sobre o que bem lhe aprouver;

d) o que efetivamente acontece se o projeto não é analisado em tempo hábil. Em alguns casos ele é transformado em lei;

e) se existe ou não a possibilidade do Congresso rejeitar o pedido de urgência;

f) se há limite para o número de pedidos, ou se a quantidade a ser enviada é decidida pelo presidente da República.

Com base nesses indicadores, a Tabela 10 estabelece pontuações mais altas quando a intervenção do Executivo é menor. Além disso, os prazos de apreciação pelo Legislativo, o leque de temáticas admitidas e a solução adotada em caso de não apreciação, foram considerados os três indicadores mais decisivos, recebendo peso mais alto na tabela.

A constituição argentina não adota esse mecanismo institucional, recebendo pontuação de máxima desconcentração nesse quesito. As constituições do Brasil (art. 64) e Uruguai (art. 168, § 7º) incorporam o pedido de urgência com uma série de especificidades que aumentam a capacidade de o Executivo intervir. Por exemplo, no Brasil não é prevista a possibilidade de derrubada do pedido de urgência e no Uruguai o projeto do Executivo será a provado, se não for apreciado em tempo hábil. Com isso, o Executivo sai fortalecido nestes dois países.

\section{O Decreto de Necessidade e Urgência}

Dentre as prerrogativas constitucionais que concentram poder decisório, certamente a capacidade de editar decretos de relevância e urgência com força de lei é a que mais favorece o Poder Executivo. Na América Latina, ela aparece em cinco países: Argentina, Brasil, Chile, Colômbia e Peru ${ }^{30}$. Argentina e Brasil têm utilizado intensamente esse mecanismo. No Uruguai essa legislação não existe.

Na Argentina, o decreto deve ser submetido em 10 dias à consideração de uma comissão bicameral que deve analisar a medida e despachá-la para que seja apreciada pelo plenário. A norma constitucional ainda 
Tabela 10

Pedido de Urgência

\begin{tabular}{|c|c|c|c|c|c|c|}
\hline Indicadores & Peso & & Ponto & Argentina & Brasil & Uruguai \\
\hline Momento do envio & 1 & $\begin{array}{l}\text { Não há urgência } \\
\text { Com o projeto } \\
\text { Qualquer }\end{array}$ & $\begin{array}{c}1,0 \\
0,5 \\
0 \\
\end{array}$ & 1,0 & 0,5 & 0,5 \\
\hline $\begin{array}{l}\text { Prazos de apreciação no } \\
\text { Congresso }\end{array}$ & 2 & $\begin{array}{l}\text { Não há urgência } \\
30-60 \text { dias } \\
\text { 10-30 dias } \\
\text { - de } 10 \text { dias }\end{array}$ & $\begin{array}{c}1,0 \\
0,5 \\
0,25 \\
0 \\
\end{array}$ & 1,0 & 0,5 & 0,5 \\
\hline Temáticas & 2 & $\begin{array}{l}\text { Não há urgência } \\
\text { Específicas } \\
\text { Limitadas } \\
\text { Ilimitadas }\end{array}$ & $\begin{array}{c}1,0 \\
0,5 \\
0,25 \\
0 \\
\end{array}$ & 1,0 & 0,25 & 0,25 \\
\hline $\begin{array}{l}\text { Resultado pela não apre- } \\
\text { ciação }\end{array}$ & 2 & $\begin{array}{l}\text { Não há urgência } \\
\text { Tranca a pauta } \\
\text { Aprovada }\end{array}$ & $\begin{array}{c}1,0 \\
0,5 \\
0\end{array}$ & 1,0 & 0,5 & 0 \\
\hline Derrubada da urgência & 1 & $\begin{array}{l}\text { Não há urgência } \\
\text { 3/5 da Câmara } \\
\text { 2/3 Câmara } \\
\text { Não é possível }\end{array}$ & $\begin{array}{c}1,0 \\
0,5 \\
0,25 \\
0 \\
\end{array}$ & 1,0 & 0 & 0,5 \\
\hline Limite do $\mathrm{n}^{\circ}$ de envio & 1 & $\begin{array}{l}\text { Não há urgência } \\
\text { Há limite } \\
\text { Não há limite }\end{array}$ & $\begin{array}{c}1,0 \\
0,5 \\
0 \\
\end{array}$ & 1,0 & 0 & 0,5 \\
\hline \multicolumn{4}{|l|}{ Média Ponderada } & 1,0 & 0,31 & 0,37 \\
\hline
\end{tabular}

Fontes: Elaborada com base em Colomer e Negretto (2003); García Montero (2004); Alcántara Sáez, García Montero e Sánches López (2005a; 2005b); Constitución de la República Oriental del Uruguay; Constituição da República Federal do Brasil e Constitución de la Nación Argentina.

frisa que uma lei, aprovada por maioria absoluta da casa, deve regular a atividade e a competência dessa comissão. Contudo, passados mais de 11 anos desde a promulgação da última Constituição argentina, a comissão ainda não foi criada. Nesse sentido, o poder do presidente da República em relação à edição dos decretos de urgência permanece imenso (Quiroga, 2005).

No Brasil, a edição e a reedição de decretos tem sido rotina desde que foram regulamentados, em 1988; durante o governo Fernando Henrique Cardoso, esse número cresceu enormemente, com centenas de medidas provisórias sendo reeditadas sem passar pela apreciação do Congresso Nacional. Tal prática foi interrompida em setembro de 2001, 
quando a Emenda Constitucional no 32 passou a permitir uma única reedição, obrigando o Legislativo a apreciar a matéria. Esta mesma emenda também impôs uma série de restrições temáticas ao uso dos decretos de urgência, prevendo a perda de eficácia, no caso da nãoapreciação. Outro fato relevante é a análise da constitucionalidade da norma, que é feita no Brasil pela Comissão de Constituição e Justiça do Congresso Nacional.

A Tabela 11 procura pontuar os limites constitucionais ao uso dos decretos de urgência nos países da América Latina. O Uruguai, que não adota a medida, foi colocado no ponto máximo de dispersão de poder. Para elaboração da tabela foram consultadas (além das constituições da Argentina, Brasil e Uruguai) as constituições do Chile, Peru e Colômbia, os três países da América Latina que também adotam a prerrogativa dos decretos de urgência.

Tabela 11

Limites ao Uso dos Decretos de Necessidade e Urgência

\begin{tabular}{|c|c|c|c|c|c|}
\hline \multicolumn{2}{|l|}{ Indicadores } & Ponto & Argentina & Brasil & Uruguai \\
\hline $\begin{array}{l}\text { Poder de De- } \\
\text { creto }\end{array}$ & $\begin{array}{l}\text { Não há } \\
\text { Restrita ao econômico } \\
\text { Com restrições } \\
\text { Sem restrições }\end{array}$ & $\begin{array}{c}1,0 \\
0,5 \\
0,25 \\
0 \\
\end{array}$ & 0,25 & 0,25 & 1,0 \\
\hline $\begin{array}{l}\text { Prazo para } \\
\text { perda de efi- } \\
\text { cácia da me- } \\
\text { dida }\end{array}$ & $\begin{array}{l}\text { Não há decreto } \\
\text { Há prazo } \\
\text { Não há limite }\end{array}$ & $\begin{array}{c}1,0 \\
0,5 \\
0\end{array}$ & 0 & 0,5 & 1,0 \\
\hline $\begin{array}{l}\text { Controle so- } \\
\text { bre constitu- } \\
\text { cionalidade } \\
\text { do decreto }\end{array}$ & $\begin{array}{l}\text { Não há decreto } \\
\text { Há controle } \\
\text { Não há controle }\end{array}$ & $\begin{array}{c}1,0 \\
0,5 \\
0\end{array}$ & 0 & 0,5 & 1,0 \\
\hline Média & & & 0,08 & 0,42 & 1,0 \\
\hline
\end{tabular}

Fonte: Elaborada com base em Alcántara Sáez, García Montero e Sánches López (2005a); Colomer e Negretto (2003); Constitución de la República Oriental del Uruguay; Constituição da República Federal do Brasil; Constitución de la Nación Argentina; Constitución Política de la República de Chile; Constitución Política de Colombia e Constitución Política del Perú.

A Argentina não impõe restrições ao uso de decretos, encontrando-se próxima ao nível máximo de concentração de poder. O Brasil aproxima-se do ponto médio, pois a Emenda Constitucional no 32 - EC 32 impôs alguns limites ao Executivo, visto que obriga o Legislativo a pronunciar-se. Entretanto, ainda hoje, o governo permanece editando um número muito alto de medidas provisórias - $\mathrm{MPs}^{31}$. 
De todo modo, no Brasil, o percentual de decretos de urgência que se transformou em projetos de lei de conversão depois da emenda restritiva cresceu substancialmente. Isso demonstra o aumento da participação do Legislativo na tramitação das MPs, sobretudo durante o governo Lula (Oliveira, 2004). Outro dado a ser considerado é que o acúmulo de MPs à espera de votação no Congresso tem levado a freqüentes situações de "trancamento de pauta".

O decreto de necessidade e urgência é considerado pela literatura política como o mecanismo mais poderoso a serviço do presidente da República, pois como se torna lei no momento da edição, cria uma situação de fato difícil de ser revertida; e mesmo quando é transformado em projeto de lei de conversão mantém os prazos curtos de trâmite, limitando demasiadamente a possibilidade de debate parlamentar.

\section{Lei Delegada}

As chamadas leis delegadas oferecem igualmente grande poder ao Executivo, possibilitando que determinadas matérias legislativas sejam delegadas ao presidente da República por um determinado tempo. Elas são permitidas na Argentina (art. 76), Brasil (art. 68) e Peru (art. 104). O Uruguai não adota essa medida.

Brasil e Argentina apresentam uma série de restrições ao uso da lei delegada. Nestes dois casos, o poder do Executivo é menor, aproximando-se do ponto médio.

É importante lembrar que Argentina, Brasil e Peru são os únicos países da América Latina que apresentam conjuntamente as duas modalidades de iniciativa do Executivo: o decreto de necessidade e urgência e a lei delegada. No caso da Argentina, a delegação só é permitida para legislação administrativa e de emergência pública; possui prazo para perda de eficácia e só pode ser usada sob determinadas condições impostas pelo Legislativo. O Brasil oferece mais liberdade legal para a edição da lei delegada, mas também aqui o controle do Legislativo é nítido. Provavelmente por esse motivo, os governos brasileiro e argentino têm preferido utilizar os decretos. No Brasil, desde 1988, foram aprovadas somente duas leis delegadas, ambas em 1992 (Pessanha, 2002, Anexo II). Na Argentina, durante o governo Menem, no entanto, a delegação foi muito utilizada, sendo inclusive responsável pela Reforma Tributária que, constitucionalmente, é de iniciativa exclusiva do Legislativo (Quiroga, 2005). 
Tabela 12

Limites ao Uso das Leis Delegadas

\begin{tabular}{|c|c|c|c|c|c|}
\hline \multicolumn{2}{|l|}{ Indicadores } & \multirow{3}{*}{\begin{tabular}{|c|} 
Ponto \\
1,0 \\
0,5
\end{tabular}} & \multirow{5}{*}{$\begin{array}{c}\text { Argentina } \\
0,5\end{array}$} & \multirow[t]{2}{*}{ Brasil } & \multirow{2}{*}{$\begin{array}{c}\text { Uruguai } \\
1,0\end{array}$} \\
\hline \multirow{4}{*}{$\begin{array}{l}\text { Poder de dele- } \\
\text { gar }\end{array}$} & Não há & & & & \\
\hline & $\begin{array}{l}\text { Leg. Administrativa e de } \\
\text { emergência pública }\end{array}$ & & & & \\
\hline & Com restrições & 0,25 & & 0,25 & \\
\hline & Sem restrições & 0 & & & \\
\hline \multirow{3}{*}{$\begin{array}{l}\text { Prazo para per- } \\
\text { da de eficácia da } \\
\text { medida }\end{array}$} & Não há lei delegada & 1,0 & & & 1,0 \\
\hline & Há prazo & 0,5 & 0,5 & 0,5 & \\
\hline & Não há limite & 0 & 0 & & \\
\hline \multirow{3}{*}{$\begin{array}{l}\text { Com procedi- } \\
\text { mentos estabele- } \\
\text { cidos pelo Con- } \\
\text { gresso }\end{array}$} & Não há decreto & 1,0 & & & 1,0 \\
\hline & Há controle & 0,5 & 0,5 & 0,5 & \\
\hline & Não há controle & 0 & 0 & & \\
\hline \multicolumn{3}{|l|}{ Média } & 0,5 & 0,42 & 1,0 \\
\hline
\end{tabular}

Fonte: Elaborada com base em Alcántara Sáez, García Montero e Sánches López (2005a); Constitución de la República Oriental del Uruguay; Constituição da República Federal do Brasil; Constitución de la Nación Argentina; Constitución Política del Perú.

\section{CONCLUSÃO}

As médias ponderadas apresentadas nas tabelas anteriores são colocadas na Tabela 13 com o objetivo de determinar um índice de concentração versus dispersão de poder nos três países. Normas constitucionais, por si sós, não são suficientes para moldar o caráter mais consensual ou mais majoritário de uma democracia, mas elas são importantes para delimitar as regras de procedimentos políticos. Além disso, analisando-se o perfil constitucional dos países, é possível visualizar o nível de equilíbrio ideológico-político daquele dado momento. Cartas constitucionais são pactos resultantes de embates entre forças políticas divergentes.

Observando-se as três constituições, é perceptível a influência que receberam das concepções econômicas liberalizantes vigentes na década de 1990. Essas novas medidas tiveram o objetivo expresso de fortalecer o Executivo, dotando-o de mecanismos garantidores da eficácia decisória. Mas o impacto dessas reformas foi muito diferente em cada caso. A Argentina praticamente refez sua constituição em 1994. No Brasil, a Constituição promulgada em 1988 constitucionalizou direitos sociais e regras econômicas que não foram, em substância, modificados pelas 
emendas constitucionais aprovadas desde aquela data. Mas já em 1988 a Constituição brasileira continha elementos que favoreciam a centralização decisória. O Uruguai manteve com a democratização a carta constitucional de 1967, de tendência consensual e nacionalista. Durante a década de 1990 foram realizadas no Uruguai reformas constitucionais com a finalidade de oferecer maior autonomia ao presidente da República.

O perfil dos três desenhos institucionais é visualizado na Tabela 13 e no Gráfico, havendo uma preocupação em apresentar a carta constitucional em dois aspectos: com a média parcial, que mostra os indicadores relativos ao processo legislativo propriamente dito, e com a média total, que incorpora ao índice os cinco indicadores que, declaradamente, têm a finalidade de concentrar poderes nas mãos do presidente da República.

A média total na Argentina - 0,37 - denota que este é o modelo mais centralizado entre as três democracias estudadas. A carta constitucional possui essa característica em seu todo, pois mesmo a média parcial da Tabela 13 é bastante baixa (valor 0,33 ). Coloca poucos obstáculos às mudanças das regras, com simples maiorias sendo em geral suficientes para aprovar a legislação. O país possui alguns mecanismos institucionais de participação social direta e de controle do Legislativo sobre o Executivo (sobretudo na lei orçamentária e nos mecanismos de accountability horizontal). Mas o sistema eleitoral e as regras de funcionamento interno do Legislativo servem para fortalecer o Executivo. Os indicadores referentes às iniciativas do Executivo apenas corroboram a mesma tendência. O controle constitucional do presidente da República dá-se primordialmente através da capacidade de veto e de edição de decretos de necessidade e urgência (a média de ambos aproxima-se do zero).

O Uruguai é o país mais consensual (média 0,64). Sua constituição é detalhista, apresentando um número extenso de normas e temáticas que, para serem regulamentadas ou reformadas, exigem maiorias especiais. Prevê, ainda, a participação direta da sociedade por meio de referendos e adota mecanismos legislativos bastante consensuais, como um sistema eleitoral fortemente proporcional e regras internas do Legislativo que favorecem a ação dos partidos oposicionistas.

É fato que também o Uruguai preocupou-se em dotar a Constituição de mecanismos que favoreçam a atuação do Executivo. Várias normas 
Tabela 13

Índice de Dispersão do Poder: Argentina, Brasil e Uruguai*

\begin{tabular}{l|c|c|c}
\hline Indicadores & Argentina & Brasil & Uruguai \\
\hline Participação da sociedade & 0,45 & 0,60 & 0,55 \\
Incentivos da lei eleitoral & 0,45 & 0,58 & 0,60 \\
Processo Legislativo & 0,22 & 0,62 & 0,72 \\
Exigência de maiorias & 0,11 & 0,40 & 1,0 \\
Questões com status Constitucional & 0 & 1,0 & 0,75 \\
Controle do Legislativo sobre o Executivo & 0,58 & 0,46 & 0,58 \\
Lei Orçamentária & 0,50 & 0,37 & 0,42 \\
Média Parcial & $\mathbf{0 , 3 3}$ & $\mathbf{0 , 5 8}$ & $\mathbf{0 , 6 6}$ \\
\hline Mecanismos de Controle do Executivo & 0,50 & 0,17 & 0,42 \\
Iniciativa exclusiva do Executivo & 0,06 & 0,31 & 0,25 \\
Veto presidencial & 1,0 & 0,31 & 0,37 \\
Pedido de urgência & 0,08 & 0,42 & 1,0 \\
Decretos de necessidade e urgência & 0,50 & 0,42 & 1,0 \\
Lei Delegada & $\mathbf{0 , 3 7}$ & $\mathbf{0 , 4 7}$ & $\mathbf{0 , 6 4}$ \\
\hline Média Total
\end{tabular}

Fonte: Elaboração da autora.

* 0 indica máxima concentração de poder e 1 máxima desconcentração.

têm essa tendência, como o processo de controle orçamentário e a legislação de iniciativa exclusiva do presidente da República. Mas é pela adoção do veto presidencial e do pedido de urgência que o Executivo realmente se fortalece no Uruguai. É importante notar, todavia, que dois dos mecanismos mais decisivos - decretos de necessidade e urgência e lei delegada - não existem na Constituição, o que interfere significativamente no sentido de torná-la mais consensual. O Gráfico 1 mostra que, de modo homogêneo, o poder no Uruguai é mais desconcentrado, com médias parciais e totais praticamente idênticas.

O Brasilé, certamente, o caso mais complexo. A primeira parte da Tabela 13 demonstra que a Constituição apresenta uma tendência ao consenso. O país adota todos os mecanismos de participação direta, contém inúmeros temas com status constitucional, possui um sistema político-eleitoral bastante permissivo e regras de funcionamento legislativo que tendem a desconcentrar o poder. É certo que não adota mecanismos de caráter parlamentarista - voto de confiança e moção de censura - como o fazem a Argentina e o Uruguai e, no processo orçamentário, a interferência do presidente da República é alta. Mas, no geral, o Brasil apresenta formas de equilíbrio entre poderes que lhe garantem uma média parcial com tendência à desconcentração. 


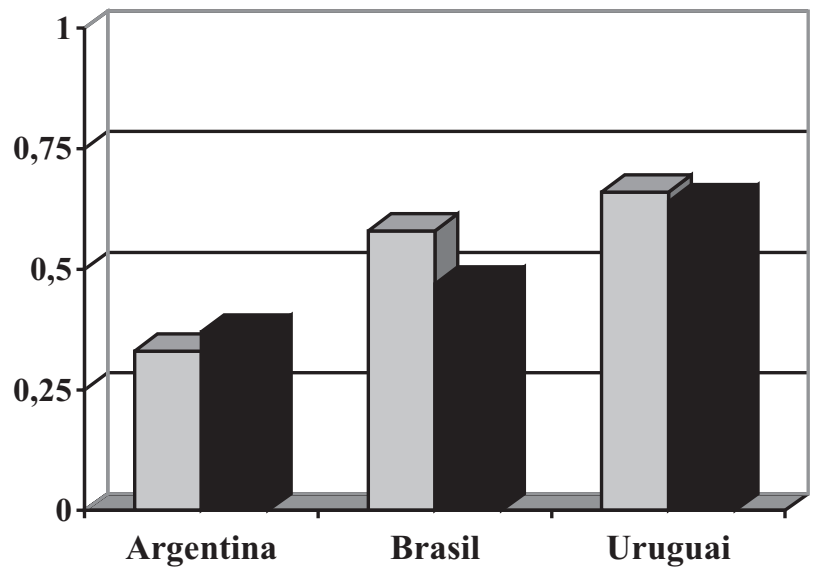

Fonte: Elaboração da autora.

Por outro lado, a Tabela 13 mostra que a Constituição brasileira oferece inúmeras possibilidades de controle do Executivo sobre o processo legislativo: o número de temas legais com exclusividade de origem no Executivo é muito alto, e ainda há a possibilidade de veto presidencial, pedido de urgência e direito de editar decretos e leis delegadas. Há, portanto um descompasso entre as duas orientações: de um lado, a Constituição desconcentra; de outro, ela centraliza ${ }^{32}$. A Tabela 13 demonstra que, na média total, ocorre um recuo significativo na escala em virtude dos poderes constitucionais do presidente da República. No gráfico, essa situação fica mais visível.

Nota-se assim que, relativamente à concentração ou dispersão de poder, os três países apresentam significativas diferenças. É claro que para conhecer o processo político efetivo dessas democracias seria necessário analisar outras variáveis que não foram consideradas aqui. $\mathrm{O}$ artigo também não adota a preocupação normativa de privilegiar um modelo em lugar de outro. O objetivo foi apenas mostrar que os sistemas presidencialistas latino-americanos apresentam desenhos institucionais muito diversos.

(Recebido para publicação em dezembro de 2005)

(Versão definitiva em maio de 2006) 


\section{NOTAS}

1. Além dos vetos institucionais, Tsebelis refere-se também aos veto players partidários, os quais ele descreve detidamente neste artigo. E sugere que a análise sobre a prerrogativa dos vetos seja ampliada para outras categorias do sistema.

2. Apenas as tabelas 5 e 8 basearam-se somente nas informações relativas aos três países, em virtude da ausência de dados mais abrangentes.

3. A prerrogativa da iniciativa popular tem tido muito pouca receptividade nos países da América Latina em que está regulamentada (10 países), resultando em um número ínfimo de projetos propostos e um número ainda menor de projetos aprovados.

4. O Uruguai é o único país da América Latina que prevê essa possibilidade: o projeto deve conter a assinatura de $10 \%$ dos eleitores e ser submetido imediatamente à decisão popular (art. 331A e B), Constitución de la República Oriental del Uruguay).

5. Art.114, Reglamento Interno de la Honorable Cámara de Diputados de la Nación; art. 58, §2으I, Constituição da República Federativa do Brasil; art. 24, Regulamento Interno da Câmara de Deputados; art. 90, Regulamento Interno do Senado Federal.

6. E nem se está cogitando aqui que deveria ser assim, pois isso significaria uma quebra do próprio sentido da representação política.

7. A iniciativa popular é regulada na Argentina pela Lei no $24.747 / 96$ e no Brasil pela Lei no $9.709 / 88$.

8. Brasil: art. 14 e art. 49, XV, Constituição da República Federativa do Brasil e Lei no 9.709 /98; Argentina: art. 40, Constitución de la Nación Argentina e Lei nํ25.432/01.

9. Há impedimento de legislar sobre tributos e sobre questões de restrita iniciativa do Executivo.

10. Na literatura política há controvérsias sobre o efetivo impacto do federalismo no processo decisório. Um balanço dessa discussão pode ser encontrado em Stepan (1999). Em relação ao caso brasileiro, autores como Ames (2003) e Samuels (2003) acreditam que os governadores exercem real capacidade de veto no Congresso Nacional, enquanto outros, como Cheibub, Figueiredo e Limongi (2002), defendem opinião oposta.

11. Como se sabe, a câmara baixa (de deputados) representa os cidadãos, indistintamente. A Venezuela, a partir da Constituição de 1999, tornou-se o único país latino-americano federalista/ unicameral. Ver: Anastasia, Melo e Santos (2004).

12. No Uruguai, a eleição nas duas casas legislativas dá-se pelo sistema de representação proporcional, em distrito único nacional (art. 88 e art. 94 a 96, Constitución de la República Oriental del Uruguay). Sánchez López (2004:87) analisou o grau de correspondência partidária na composição dos legislativos bicamerais da América Latina, mostrando que, de modo geral, a representação é similar nas duas casas. Mas ele salienta que o caso uruguaio se destaca pela "enorme homogeneidade".

13. O termo "sistema misto", utilizado na Tabela 2, foi retirado de Colomer e Negretto (2003). Mas é importante lembrar que se trata de uma fórmula específica, não se referindo ao sistema eleitoral proporcional personalizado, popularmente conhecido como sistema distrital misto. Para maiores detalhes, ver nota 15.

14. O argumento de Mariana Llanos, citada por Navarro (2004:75), é que o Legislativo do Brasil e o da Argentina são simétricos porque o Senado pode modificar e rechaçar 
qualquer legislação, assim como apresentar seus próprios projetos em qualquer área temática e, em caso de desacordo, a decisão final cabe à câmara de origem. No Uruguai, a solução de conflitos dá-se em assembléia conjunta das duas câmaras, e como não há contagem separada dos votos, somente a Câmara Baixa, mais numerosa, pode ter os votos decisivos.

15. No Brasil, são três senadores por estado, eleitos a cada quatro anos para um mandato de oito anos, alternando-se a magnitude do distrito para uma e duas cadeiras a cada eleição (art. 46). Na Argentina, a magnitude do distrito é sempre igual a três, em cada província. Duas cadeiras ficam para o partido mais votado e a terceira vai para o segundo partido mais votado (art. 54). A eleição acontece a cada dois anos para um mandato de seis, com uma renovação periódica de oito províncias a cada eleição (art. $56)$.

16. No Brasil, a magnitude dos 27 distritos varia entre 8 e 70 cadeiras, com média igual a 19. Na Argentina, a variação da magnitude nos 24 distritos varia entre 2 e 35 cadeiras e as eleições são realizadas a cada biênio, renovando-se sempre $50 \%$ das cadeiras da Câmara de Deputados. Assim, a magnitude média na Argentina é menor que três, provocando grande desproporcionalidade no cálculo de cadeiras. Ver Anastasia, Melo e Santos (2004).

17. Mainwaring e Shugart (1999) destacam que o sistema uruguaio é sui generis, pois as listas sobrepostas não favorecem a centralização partidária, mas sim as facções partidárias; é, portanto, considerado um sistema mais desconcentrado do que o sistema puro de listas fechadas.

18. Não foram consideradas aqui nem a fórmula eleitoral nem a magnitude do distrito, que funcionam igualmente como mecanismos de exclusão (Lijphart, 1994). No Brasil, a Lei n-9.996/95 estabeleceu a cláusula de barreira de 5\% a partir das eleições de 2006, mas o projeto de Reforma Política (PLC nํ⒉679/03) rebaixou esse percentual para $2 \%$ nas eleições posteriores a 2006.

19. A idéia é retirada de Sartori (2004), que faz uma ampla discussão sobre os efeitos dos sistemas eleitorais e partidários sobre o número de partidos parlamentares.

20. Segundo o Programa das Nações Unidas para o Desenvolvimento - PNUD (2004, Tabela 37), o índice de desproporcionalidade na Câmara de Deputados entre 1990-2002 foi de 6,69 na Argentina; 3,81 no Brasil e 0,65 no Uruguai. A média latino-americana no período foi de 5,63. Segundo a mesma fonte (Tabela 32), no mesmo período o número de partidos parlamentares efetivos foi de 2,92 na Argentina; 8,12 no Brasil; 3,19 no Uruguai.

21. Trata-se de uma afirmação polêmica, baseada na suposição de que o poder Executivo detém o controle do processo Legislativo graças aos recursos políticos e institucionais que utiliza. Mesmo não acatando integralmente essa tese, há um consenso de que o Colégio de Líderes centraliza os trabalhos legislativos nas mãos das lideranças partidárias.

22. OChile apresenta um caso isolado de exigência de $4 / 7$ dos presentes para aprovação de lei orgânica, mas a coluna foi eliminada para facilitar a tabela.

23. Na Argentina, são três: direitos civis, políticos e sociais; política de educação; índios. No Brasil, são 13: direitos civis, políticos e sociais; administração e emprego público; sistema tributário; orçamento da União; monopólios da União; política agrícola e fundiária; política de saúde; previdência, pensões, aposentadorias; assistência social 


\section{Luzia Helena Herrmann de Oliveira}

e família; política de educação; meios de comunicação; meio ambiente; índios. No Uruguai, são 10: direitos civis, políticos e sociais; administração e emprego público; orçamento da união; assistência social e família; política de educação; meio ambiente; serviços estatais (entes autônomos); política industrial; água e saneamento.

24. Accountability Horizontal nos termos de O'Donnell (1998).

25. Segundo os autores, os motivos são: 1) mau desempenho; 2) delitos relativos ao cargo; 3) delitos comuns; 4) atos que comprometem a segurança e a honra da nação; 5) infração à Constituição; 6) enriquecimento ilícito; 7) impedimento de regras democráticas. Na Tabela 6 está assim considerado: 1) mau desempenho; 2) delitos relativos ao cargo, crime de responsabilidade, atos que comprometem a nação, infração à Constituição, impedimento às regras democráticas; 3 ) crimes comuns e enriquecimento ilícito.

26. Cabe lembrar que Alcántara Sáez, García Montero e Sánches López (2005b) também elaboraram um índice de controle, utilizando pontuações e critérios ligeiramente diferentes. Aplicando-se ao índice deles a divisão de concentração e dispersão proposta neste trabalho, os resultados serão idênticos.

27. Em todos os casos sempre cabe a iniciativa ao Executivo, mas determinadas constituições aceitam a iniciativa do Legislativo em casos excepcionais. São elas as da Bolívia, Panamá e República Dominicana.

28. O grau de iniciativa legislativa do Executivo tende a ser muito alto no Brasil, alto no Uruguai e mediano na Argentina. Da legislação aprovada na Argentina, entre 1997 e 2004, 44,55\% tiveram origem no Executivo; no Brasil, esse percentual entre 1989 e 1998 foi de 71\%; no Uruguai, foi de 60,60\% entre 1995 e 2002 (Alcántara Sáez, García Montero e Sánches López, 2005a, Tabelas 15 e 27; Figueiredo, Limongi e Valente, 2000:53).

29. Brasil, Chile, Equador, Paraguai, Peru e Uruguai (Colomer e Negretto, 2003).

30. Art. 99, 3, Constitución de la Nación Argentina; art. 62, Constituição da República Federal do Brasil; art. 60, Constitución Política de la República de Chile; art. 150, 10, Constitución Política de Colombia e art.118, 19, Constitución Política del Perú.

31. Foram editadas 166 MPs entre janeiro de 2003 e dezembro de 2006 (https://www.planalto.gov.br/).

32. Como atestam alguns autores, esse determinante constitucional parece influir decisivamente no processo político: "Considerando-se que os maiores partidos mal chegam a 20\% das cadeiras cada um, isso significa que, desde 1988, o Executivo tem estado à mercê do Legislativo em todas as questões que envolvem alteração da Constituição. No sentido inverso, a prerrogativa de legislar por decreto (MPs) conferiu ao Executivo um poder virtualmente incontrastável em relação à legislação ordinária. Portanto, não há exagero em afirmar que a Constituição de 1988 tornou o Congresso refém do Executivo em todas as questões referentes à legislação ordinária; e o presidente refém do Congresso em tudo que requer reforma constitucional" (Lamounier, 2005:245). 


\section{REFERÊNCIAS BIBLIOGRÁFICAS}

ALCÁNTARA SÁEZ, Manuel, GARCÍA MONTERO, Mercedes e SÁNCHES LÓPEZ, Francisco (compiladores). (2005a), El Poder Legislativo en América Latina a través de sus Normas. Salamanca, Ediciones Universidad de Salamanca.

. (2005b), Funciones, Procedimientos y Escenarios: Un Análisis del Poder Legislativo en América Latina. Salamanca. Ediciones de la Universidad de Salamanca.

AMES, Barry. (2003), Os Entraves da Democracia na Brasil. Rio de Janeiro, Fundação Getulio Vargas Editora.

ANASTASIA, Fátima, MELO, Carlos Ranulfo e SANTOS, Fabiano. (2004), Governabilidade e Representação Política na América do Sul. Rio de Janeiro/São Paulo, Fundação Konrad Adenauer/Unesp.

ARGENTINA. Constitución de la Nación Argentina. Disponível em http:/ / www.senado.gov.ar/web/interes/constitucion/cuerpo1.php

BRASIL. Constituição da República Federal do Brasil. Disponível em http:/ / www.senado.gov.br/sf/legislacao/const/

CHEIBUB, José Antonio, FIGUEIREDO, Argelina e LIMONGI, Fernando. (2002), Presidential Agenda Power and Decision Making in Presidential Regimes: Governors and Political Parties in the Brazilian Congress. Trabalho apresentado no XXVI Encontro Anual da ANPOCS, Caxambu, 22-26 de outubro.

CHILE. Constitución Política de la República de Chile. Disponível em http:/ / www.defensoriapenal.cl/archivos/1092838070.pdf

COLOMBIA. Constitución Política de Colombia. Disponível em http://www.banrep.gov.co/regimen/resoluciones/cp91.pdf

COLOMER, Josep M. e NEGRETTO, Gabriel L. (2003), “Gobernanza con Poderes Divididos en América Latina". Política y Gobierno, vol. X, no 1, I semestre, pp. 13-61.

FIGUEIREDO, Argelina Cheibub e LIMONGI, Fernando. (1999), Executivo e Legislativo na nova Ordem Constitucional. Rio de Janeiro, Fundação Getulio Vargas Editora.

e VALENTE, Ana Luzia. (2000), “Governabilidade e Concentração de Poder Institucional - O Governo FHC”. Tempo Social, vol. 11, no 2, pp. 49-62.

GARCÍA MONTERO, Mercedes. (2004), “El Procedimiento Legislativo en América Latina". América Latina Hoy, vol. 38, pp. 17-55.

LAMOUNIER, Bolívar. (2005), Da Independência a Lula: Dois Séculos de Política Brasileira. São Paulo, Augurium Editora.

LANZARO, Jorge (org.). (2003), Tipos de Presidencialismo y Coaliciones Políticas en América Latina. Buenos Aires, CLACSO.

LIJPHART, Arendt. (1984), Democracies: Patterns of Majoritarian and Consensus Government in Twenty-one Countries. New Haven, Yale University Press.

. (1994), Electoral Systems and Party Systems. New York, Oxford University Press.

(2003), Modelos de Democracia. Rio de Janeiro, Editora Civilização Brasileira. 


\section{Luzia Helena Herrmann de Oliveira}

MAINWARING, Scott. (2002), Sistemas Partidários em Novas Democracias - O Caso do Brasil. Rio de Janeiro, Fundação Getulio Vargas Editora.

e SHUGART, Matthew Soberg. (1999), Presidentialism and Democracy in Latin America (2a ed.). Cambridge, Cambridge University Press.

MOLINELLI, Guillermo. (1991), Presidentes y Congresos en Argentina: Mitos y Realidades. Buenos Aires, Colección Estudios Políticos y Sociales.

NAVARRO, Marc. (2004), “Intereses Subestatales en Legislativos Bicamerales: Sobre la Cooperación Interinstitucional en Entornos Descentralizados". América Latina Hoy, vol. 38, dic, pp. 57-76.

O’DONNELL, Guillermo (1998), “Accountability, Horizontal e Novas Poliarquias". Lua Nova, no 44, pp. 27-54.

OLIVEIRA, Luzia Herrmann de. (2004), Brasil: Relação entre Executivo e Legislativo no Processo Decisório Recente. Verificação de uma Hipótese. Trabalho apresentado no 2o-Congresso da Associação Latino-Americano de Ciência Política-ALACIP, Cidade do México, 29 setembro -1o outubro.

PERÚ. Constitución Política del Perú. Disponível em http://pdba.georgetown.edu/Constitutions/Peru/per93.html.

PESSANHA, Charles. (2002), “O Poder Executivo e o Processo Legislativo nas Constituições Brasileira (Teoria e Prática)", in L. Werneck Vianna (org.), A Democracia e os Três Poderes no Brasil. Belo Horizonte/Rio de Janeiro, Ed. UFMG/Iuperj/Faperj.

PROGRAMA DAS NAÇÕES UNIDADES PARA O DESENVOLVIMENTO - PNUD. (2004), La Democracia en América Latina - Compendio Estadístico. Buenos Aires.

QUIROGA, Hugo. (2005), La Argentina en Emergencia Permanente. Buenos Aires, Edhasa.

RAE, Douglas. (1967), The Political Consequences of Electoral Laws. New Haven, Yale University Press.

SAMUELS, David. (2003), Ambition, Federalism and Legislative Politics in Brazil. New York, Cambridge University Press.

SÁNCHEZ LÓPEZ, Francisco. (2004), “Cámaras Diferentes, Partidos Iguales: Los Partidos Políticos en los Bicameralismos de Iberoamérica". América Latina Hoy, vol. 38, pp. 77-100.

SARTORI, Giovanni. (2004), Ingeniería Constitucional Comparada (3a ed.). México, Fondo de Cultura Económica.

STEPAN, Alfred. (1999), "Para uma Nova Análise Comparativa do Federalismo e da Democracia: Federações que Restringem ou Ampliam o Poder do Demos". Dados, vol. 42, no 2, pp. 197-251.

TSEBELIS, George. (1997), “Processo Decisório em Sistemas Políticos: Veto Players no Presidencialismo, Parlamentarismo, Multicameralismo e Pluripartidarismo". RBCS, vol. 12, no 34 .

URUGUAY. Constitución de la República Oriental del Uruguay. Disponível em http:/ / www.rau.edu.uy/uruguay/const97-1.6.htm 


\begin{abstract}
Presidentialisms in Comparative Perspective: Argentina, Brazil, and Uruguay
\end{abstract}

Institutional designs exert an influence on the degree of centralization or dispersion of decision-making power. This article takes a comparative approach to the institutional designs in three South American democracies Argentina, Brazil, and Uruguay - with the objective of constructing an index for concentration of power in the three countries. The indicators take three aspects into account: mechanisms for direct political participation, the legislative process with the various forms of horizontal accountability and veto among players, and the level of intervention by the Executive Branch using proactive and reactive powers. A systematic data survey shows that the designs in the three countries display major differences.

Key words: Latin American legislatures; presidentialisms in Latin America; comparative politics in Latin America

\title{
RÉSUMÉ \\ Régimes Présidentiels en Comparaison: Argentine, Brésil et Uruguay
}

Des modèles institutionnels peuvent influencer le niveau de centralisation ou de dispersion du pouvoir de décision. Dans cet article, on examine et compare les modèles institutionnels de trois démocraties en Amérique du Sud Argentine, Brésil et Uruguay - dans le but de construire un indice de concentration du pouvoir pour chacun de ces pays. On considère comme indicateurs trois aspects: les mécanismes de participation politique directe; le processus législatif et les diverses formes d'accountability horizontale et de veto entre acteurs; et le niveau d'intervention des pouvoirs proactifs et réactifs du pouvoir exécutif. La recherche systématique sur des données montre que les trois modèles présentent des différences significatives.

Mots-clé: pouvoirs législatifs en Amérique Latine; régimes présidentiels en Amérique Latine; politique comparée en Amérique Latine 